\title{
Mining at the Fringes. High-Altitude Prehistoric Copper Mining in the Oberhalbstein Valley (Grisons, Switzerland)
}

\author{
Leandra Reitmaier-Naef \\ Peter Thomas \\ Julia Bucher \\ Monika Oberhänsli \\ Caroline 0. Grutsch \\ Klaus-Peter Martinek \\ Mathias Seifert \\ Philippe Rentzel \\ Rouven Turck \\ Thomas Reitmaier \\ Philippe Della Casa
}

\begin{abstract}
The mining region of Oberhalbstein, to date sparsely studied, has been the subject of archaeological research since 2013. Two mining areas which lie well above the forest line were studied in the summer of 2017. The Avagna-Ochsenalp site includes multi-phased heap features, of which the earliest phase has been dendrochronologically dated to the $11^{\text {th }}$ century BC. In Cotschens, mining traces in an area of approximately $0.1 \mathrm{~km}^{2}$ from an unknown time period have been observed. Here, the flooded mine 1 was studied in more detail. After the cavity had been drained, 66 wood objects were revealed, including mining tools from the $1^{\text {st }}$ century BC. ${ }^{14} \mathrm{C}$ dating further confirms Late Bronze Age and Early to Late Iron Age activity. Stone tools from the adjacent heap also confirm prehistoric on-site ore processing, a unique find so far in the Oberhalbstein region.
\end{abstract}

\section{Keywords}

Mining archaeology, copper production, Central Alps, Late Bronze Age, Hallstatt period, La Tène period.

Zusammenfassung - Bergbau in Randzonen. Präbistorischer Kupferbergbau im Hochgebirge des Oberhalbsteins (Graubünden, Schweiz)

Die bislang kaum erforschte Montanregion Oberhalbstein ist seit 2013 Gegenstand archäologischer Untersuchungen. Im Sommer 2017 wurden zwei deutlich über der Waldgrenze gelegene Abbauareale erforscht. Die Fundstelle Avagna-Ochsenalp umfasst ein mehrphasiges Haldengelände, dessen älteste Phase mittels Dendrochronologie ins 11. Jh. v. Chr. datiert wurde. In Cotschens sind auf einer Fläche von ca. $0,1 \mathrm{~km}^{2}$ zahlreiche Abbauspuren unbekannter
Zeitstellung zu beobachten. Genauer untersucht wurde die abgesoffene Grube 1. Nach dem Abpumpen der feuergesetzten Hohlräume kamen 66 Holzobjekte zum Vorschein-darunter bergbauspezifische Geräte aus dem 1. Jh. v. Chr. ${ }^{14} \mathrm{C}$-Datierungen belegen hier darüber hinaus spätbronzezeitliche sowie früh- und späteisenzeitliche Aktivitäten. Im angrenzenden Haldengelände wurden außerdem Steingeräte dokumentiert, die eine prähistorische Erzaufbereitung vor Ort bezeugen - ein bisher einzigartiger Befund im Oberhalbstein.

\section{Schlüsselbegriffe}

Montanarchäologie, Kupferproduktion, Zentralalpen, Spätbronzezeit, Hallstattzeit, Latènezeit.

\section{Introduction}

The Oberhalbstein is situated in the Central Alpine region of the canton of Grisons (GR) in southeast Switzerland. It is the only region of the country in which evidence of prehistoric copper mining has been found so far. The valley is divided into a lower northern and an upper southern step (Fig. 1).

Evidence of several settlements ${ }^{1}$ on the lower valley step confirms that this area was inhabited from the $2^{\text {nd }}$ millennium BC onwards, by a society based largely on agriculture

1 Cunter-Caschligns, Salouf-Motta Vallac, Savognin-Padnal, Savognin-Rudnal. 


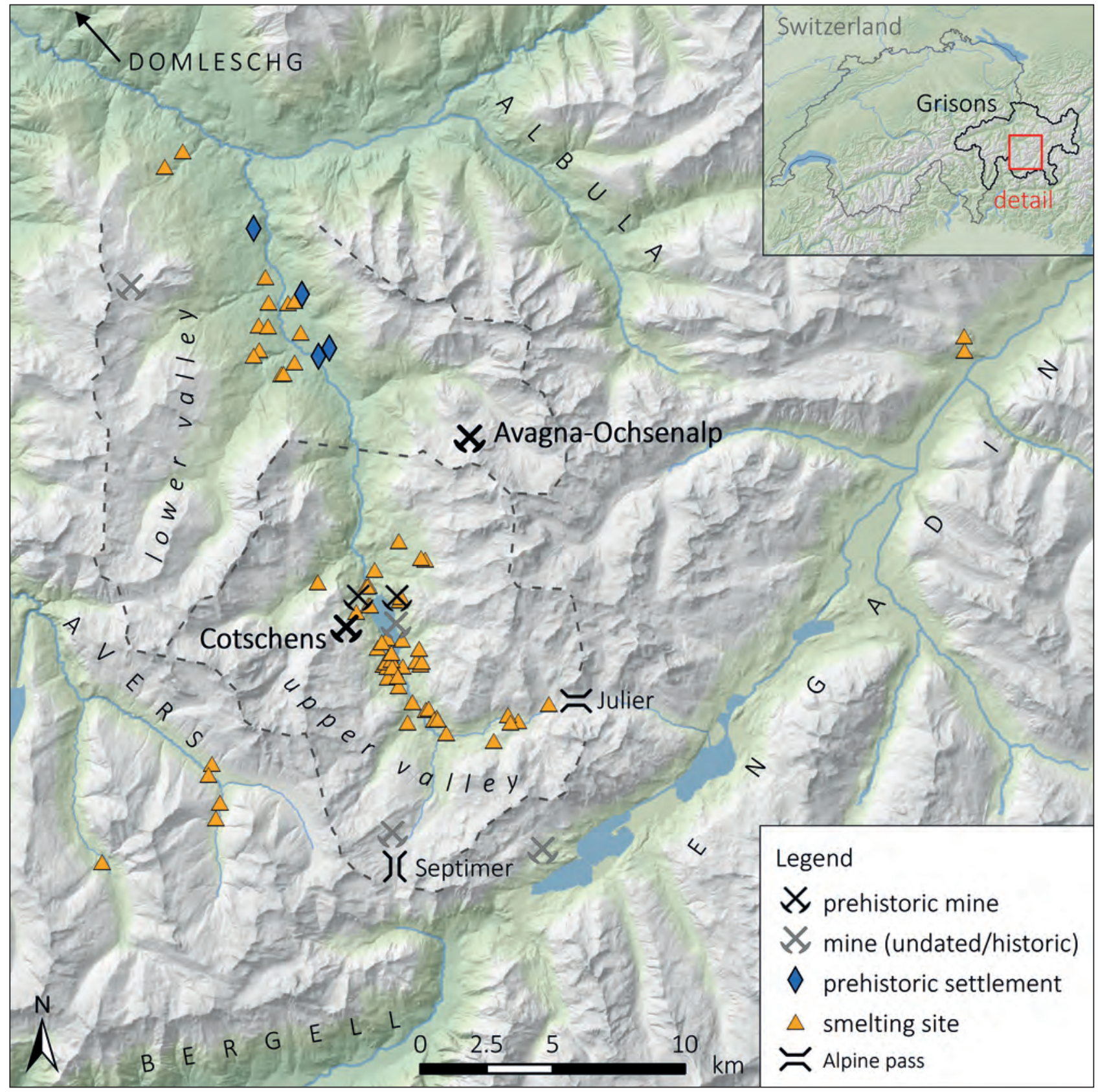

Fig. 1. Overview of the Alpine region of Oberhalbstein, showing the sites described in the text (Map: L. Reitmaier-Naef, UZH; geodata: Federal Office of Topography and Canton of Grisons).

and livestock farming. The Oberhalbstein has played an important role as an Alpine transit route at the latest since the Middle Bronze Age, connecting Domleschg and the Albula Valley in the north to Engadin and the Bergell Valley in the south, by way of the Julier and Septimer passes. ${ }^{2}$

Early evidence of local copper production - smelting sites and single finds of smelting slag in settlement contexts -

2 Rageth 1986. dates to the Late Bronze Age. ${ }^{3}$ However, mining activity in the region seems to have reached its peak in the Early Iron Age, when dozens of smelting sites and several mines were established on the upper valley step. ${ }^{4}$ Written sources for historical ore mining in the Oberhalbstein begin in the Late

3 Wyss 1993. - Schaer 2003. - FASNACHt 2004. - Wyss 2004.

4 Turck, Della Casa, Naef 2014. - Reitmaier-Naef, Turck, Della Casa 2015. - Della Casa, Naef, Turck 2016. 
Middle Ages but only sporadically document the following centuries, leaving the scope of the mining activity unknown. All of Grisons was finally seized by a full-blown mining boom during the industrialization of the early $19^{\text {th }}$ century. However, in view of the unprofitable nature of most of the mines, this came to an end towards the middle of the $19^{\text {th }}$ century, and apart from manganese mines during the world wars, there has been no mining activity in the Oberhalbstein region since. ${ }^{5}$

Prehistoric mining activity was focused around ironrich sulfidic copper ore, which crops out in several areas of the valley. These mineralizations are found only in the upper Pennine Platta nappe, which is comprised primarily of ophiolites. The mineralizations are mainly contained in serpentinite sequences, more rarely in metabasalt. ${ }^{6}$

Evidence of prehistoric metal production in the Oberhalbstein region has been known since the beginning of the $20^{\text {th }}$ century. In recent years, it has been the subject of systematic investigation by the University of Zurich's Department of Prehistory, as part of the international research project 'Prehistoric copper production in the Eastern and Central Alps'. The field work completed between 2013 and 2018 included extensive surveys as well as excavations in the areas of known smelting sites around Lake Marmorera, on the upper valley step.

While there had previously been no direct archaeological evidence of prehistoric mining activity in the investigated area, today at least four mines ${ }^{8}$ and several as yet unstudied or inaccessible potential sites are known. Two of the most striking mining sites, situated well above the forest line, are Avagna-Ochsenalp (Tinizong GR) and Cotschens (Marmorera GR) (Fig. 1). Both sites were first studied more closely in August 2017 by an international team. In advance of the field work, high-resolution orthophoto and terrain models (SfM) of both mining sites were taken with the aid of a drone. These served as a basis for further work and surveys. Subsequently, the two sites were subjected to a mining archaeological survey in order to describe, map and photograph the numerous structures and features in detail and to sample the localized mineralizations for geochemical and mineralogical investigations. Small trenches were opened at archaeologically promising spots within the heaps of both sites. The main focus, however, was on the initial investigation of mine 1 in Cotschens, whose underground part

5 BRUN 1987.

6 Dietrich 1972. - Peters, Dietrich 2008.

7 Della Casa, Naef, Turck 2016. - Turck 2019.

8 Besides the two sites presented here: Gruba II (Marmorera GR), see Turck et al. 2018. - Vals (Marmorera GR), see Reitmaier-NaEF, Turck, Della Casa 2015. is normally partially flooded. After the cavity had been drained, a substantial part of the mine was accessible for archaeological investigations for the first time. In addition to a detailed documentation of the mine, a complex profile of the underground area could be uncovered, documented and sampled. The results of these studies are presented below.

\section{Avagna-Ochsenalp}

\subsection{Mining Site}

The area known as Ochsenalp is situated between the main valley and the Val d'Err, which lies to the east and parallel to the main valley (Fig. 2). Here, the mining site Avagna (l'Avagna, Romansh: (ore) vein) is one of the few known copper mineralizations on the lower valley step. This site has long been considered the potential source of raw materials for the many known prehistoric smelting sites in the lower part of the valley. ${ }^{9}$

Written sources attest to the relatively intensive historical usage of the Avagna site compared to other mining sites in the valley. The earliest written evidence for historical mining in the Oberhalbstein region is an agreement between members of the local ministerial family 'von Marmels' on the usage of the ore veins in the Val d'Err, which dates to the year $1338 \mathrm{AD} .{ }^{10}$ The locality is named 'Jsenberg ${ }^{11}$... Emede', indicating that the extracted ore was not only used for copper at this point, but also for iron production. Despite the mineral royalties staying in the hands of the von Marmels for a further two hundred years, no further documentation for the duration and the extent of mining activity in Avagna-Ochsenalp is known. ${ }^{12}$ Several mines on the lower valley step are mentioned in the 1606 records of a mining judge named Gadmer, ${ }^{13}$ although the location of these mines is unknown today. It is unclear whether Avagna-Ochsenalp was not in use at this point, or if there are other reasons for it not being included in these records. It is certain, however, that the mineralization on the Ochsenalp was periodically exploited in the first third of the $19^{\text {th }}$ century. Beside iron and/ or copper, vitriol was also extracted from the sulphidic ores of the Ochsenalp at this time. The ruins of the Cruschetta vitriol factory, situated at the end of the Val d'Err (Fig. 2), as well as the partially preserved road for ore transportation between Avagna and Cruschetta, attest to this. ${ }^{14}$ Mining activity in Avagna came to an end in the 1830 s at the latest. This is indicated by both the lack of written mining records

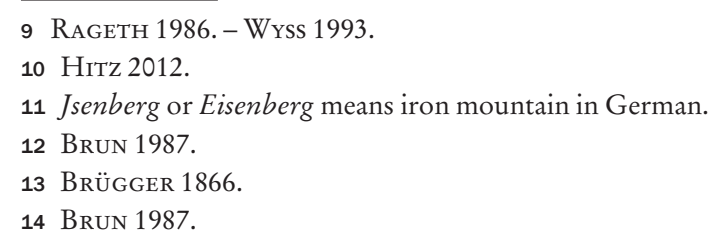




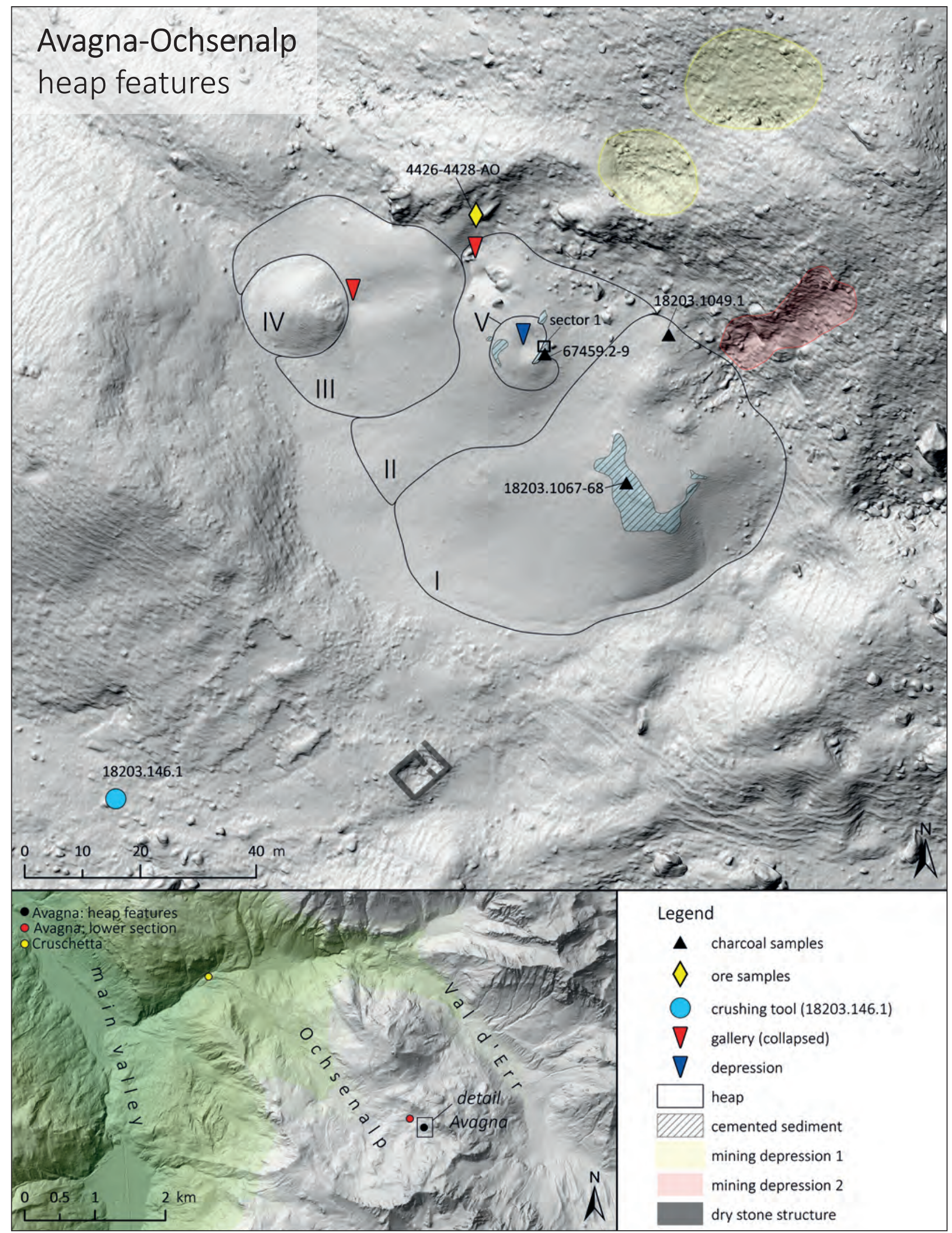

Fig. 2. Avagna-Ochsenalp, map of the described structures, finds and samples (Map: L. Reitmaier-Naef, UZH; terrain model: A. Zwicky and Ch. Walser, ADG; geodata: Federal Office of Topography and Canton of Grisons). 


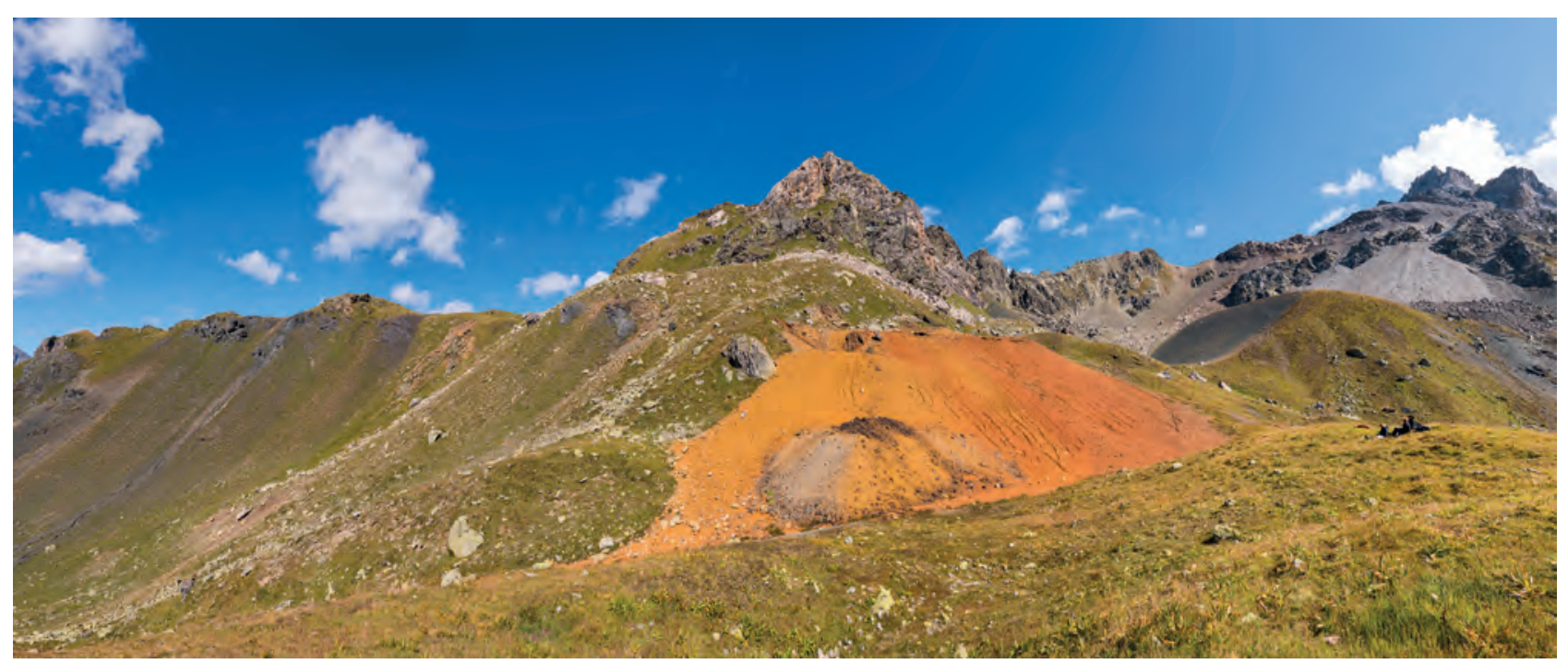

Fig. 3. Avagna-Ochsenalp, panorama of the upper section of the site with heap features (Photo: P. Thomas, DBM).

and the description of abandoned, inaccessible mines in slightly younger geological literature. ${ }^{15}$

\subsection{Description of the Mining Structures}

The site is situated in the upper part of the Ochsenalp area, which opens to the northwest, and can be divided into an upper and a lower section. These sections are separated by a distance of around $100 \mathrm{~m}$ (Figs. 2-3).

The upper section is situated at approximately 2480 masl $^{16}$. Characterized by a large heap which stands out from afar due to its striking red colouring, it lies halfway up the northeastern flank of the valley. A clearly defined step in the terrain to the southwest and northwest separates it from the slope below. The maximum extent of the area parallel to the slope is approximately $100 \mathrm{~m}$ from northwest to southeast, and approximately $70 \mathrm{~m}$ from northeast to southwest. The heap is not uniform, its shape and coloration show that it in fact consists of several features which follow each other both chronologically and spatially (Fig. 3).

One of the oldest features is a heap (I) which occupies the southeast of the site over an area of $40 \times 65 \mathrm{~m}$. Its upper section is a flattened plateau which holds debris from the slope above. Several isolated piles of rocks and mining waste are grouped around it. A similar plateau lies around $15 \mathrm{~m}$ northwest of the first heap. It can be assumed that this is a second, comparable heap (II). This heap has been disturbed by stratigraphically younger features, making its original extent difficult to determine. The older features are

15 E.g. Theobald 1862.

16 Metres above sea level. characterized by an intensive red colouring and a predominance of fine-grained mining waste.

A stratigraphically younger heap (III) adjoins the two older heaps at the northwestern end of the site. It is roughly circular and has a diameter of $40 \mathrm{~m}$. The top of heap III is also flattened, and a disturbance of the older, covered heap (II) runs from this plateau towards the northeast. Parts of the older heap were apparently removed, exposing sections of the bedrock. The mining waste in heap III is significantly yellower, the characteristic red only occurring on its southeastern side. In addition, an elongated depression runs across the surface of the heap, beginning at the upper edge and continuing down the slope in a west-southwest direction.

Another, younger heap (IV) lies below the linear depression and covers the lower part of heap III. This heap is also circular, with a diameter of $17 \mathrm{~m}$ and a mostly yellow colouring, with grey in the northwest area. The mining waste on its surface is finely grained, interspersed with larger stone blocks which show evidence of drill holes from blasting work (Fig. 4).

The fifth feature $(\mathrm{V})$ lies to the south of the disturbance in heap II, slightly beneath its peak. It is crescent shaped, with a width of $14 \mathrm{~m}$, and borders a depression with a diameter of $4 \mathrm{~m}$. Feature $\mathrm{V}$ is stratigraphically younger than feature II. Due to the lack of overlap with the other features, its temporal relation to them cannot be determined.

Beginning above the heaps, two features follow the slope upwards to the north. The northwestern feature (mining depression 1) is comprised of several depressions which can be followed over a length of approximately $50 \mathrm{~m}$. 


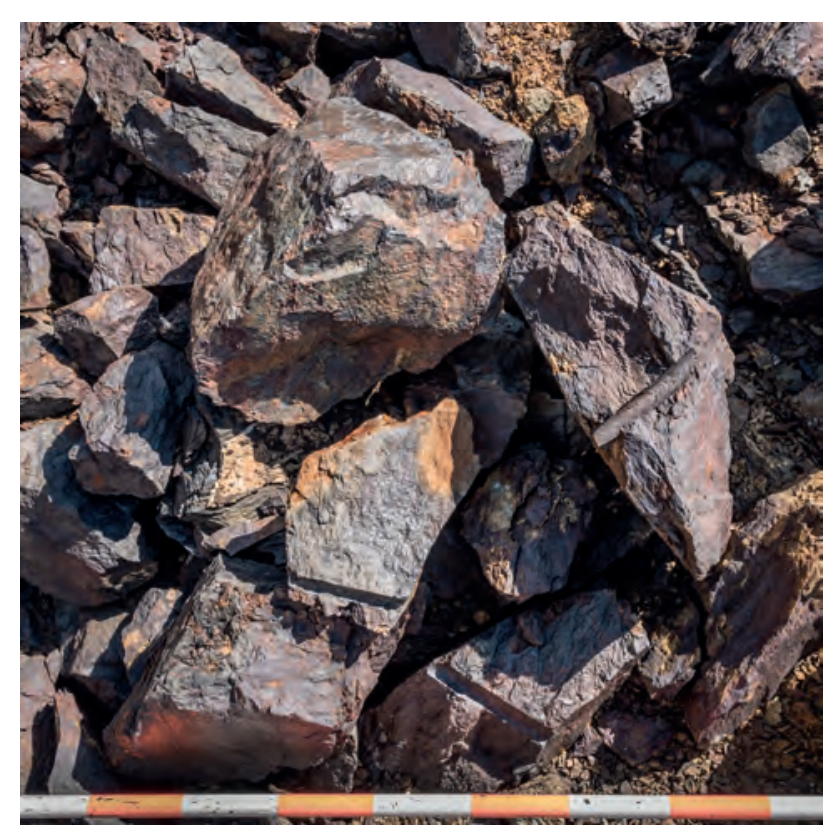

Fig. 4. Avagna-Ochsenalp, large stone blocks on heap IV with drill holes from blasting work (Photo: P. Thomas, DBM).

The southeastern feature (mining depression 2) is a distinct trench of around $25 \mathrm{~m}$ in length.

A final feature in this area of the site is the dry-stone walls of a building, which lie approximately $20 \mathrm{~m}$ to the south of the heaps (Fig. 2). The $10 \times 6 \mathrm{~m}$ structure built of rough stone blocks contains a visible partition wall, which indicates the division of the interior into at least two rooms.

A hand-held crushing tool, a so-called pestle (Fig. 19, 18203.146.1), was found on the slope below the building structure. This is the only artefact found in this area of the site. The raw material is an augite-biotite-diorite, a plutonic rock possibly originating from the bedrock of the Err nappe, which lies above the site. The artefact was artificially worked into a rounded, flattened shape. It has a relatively regular diameter of $10 \mathrm{~cm}$ and weighs just under $600 \mathrm{~g}$. Traces of use are visible on the worn edges of the tool.

The lower section of the site lies at approximately 2410 masl, northwest and down-slope, at the foot of the terrain step which borders the heap features in the upper area of the site. Several building structures and small heaps are found in this area, which extends over $125 \mathrm{~m}$ from east to west and reaches $50 \mathrm{~m}$ at its widest point. The former are two round buildings which are sunk into the ground, and the foundations of a smaller, rectangular building. One of the round structures shows evidence of burning on the inner walls. The heaps have a distinctive red colouring, and one contains a noticeable amount of stones with secondary copper mineralization. The heaps and a possible gallery situated near the rectangular building suggest that this group of finds may be connected to mining activity. However, in what period these structures were in use remains undetermined at this point.

\subsection{Description of the Findings}

Almost the entire area surrounding the heaps of the upper section, especially the steep slopes, is covered with fine, loose rubble. The red colour of the largest heaps (I and II) is most intense on the surface and changes to a yellow-grey or ochre-yellow shade in the layers beneath.

The mining waste appears as compact, layered, breccia-like cemented sediment in the upper areas of heaps I and II, especially at the edges of the plateaus (Fig. 5). Regularly occurring charcoal fragments und negative imprints of wood splints are found in these areas. Some of the wood imprints from the edge of heap I have square or rectangular cross sections of 3-8 $\mathrm{mm}$ and are occasionally found in pairs (Fig. 6).

An area of mining waste in the northwest of the heap features was excavated in a sector of $1.5 \times 2 \mathrm{~m}$, the stratigraphy was documented and sampled (Figs. 2, 5, sector 1). These layers belong stratigraphically to the older heap II and not to the younger, crescent-shaped heap V. The trench revealed a sequence of layers of differing thickness, which also differ significantly in their composition. The layers run horizontally or at a slight downhill slant. The uppermost 20-30 $\mathrm{cm}$ are the most compactly cemented, and mainly consist of rubble $(1-10 \mathrm{~cm})$ that shows varying degrees of weathering. The polished section of a micromorphological block sample (67459.4.1) of this area reveals a stratified sequence with layers a few centimetres thick. Beneath this cemented upper part lies a noticeably looser, subhorizontally bedded deposit of $10-20 \mathrm{~cm}$ thickness. It contains isolated charcoal fragments $(5-50 \mathrm{~mm})$, and partially burned, fine-grained reddish sediment. Below this follows a more compact layer which contains rock fragments up to $20 \mathrm{~cm}$ in diameter.

The polished section of a micromorphological sample from the uppermost layer of the edge of heap I shows a similar composition and an even more pronounced stratification (Fig. 7, 18203.115.1). These deposits, consisting mainly of weathered greenish to brownish serpentinite fragments (ultramafic bedrock) are strongly cemented by iron hydroxides. The angular rock fragments $(0.1-2 \mathrm{~cm})$ generally occur as elongated flakes and contain occasional ore inclusions (chalcopyrite or pyrite). The uppermost layer is dominated by big, well-preserved and subangular charcoal fragments (1-20 mm). Interestingly, in the central area of the sample, there are indications of a trampled surface on top of layer 4 , 


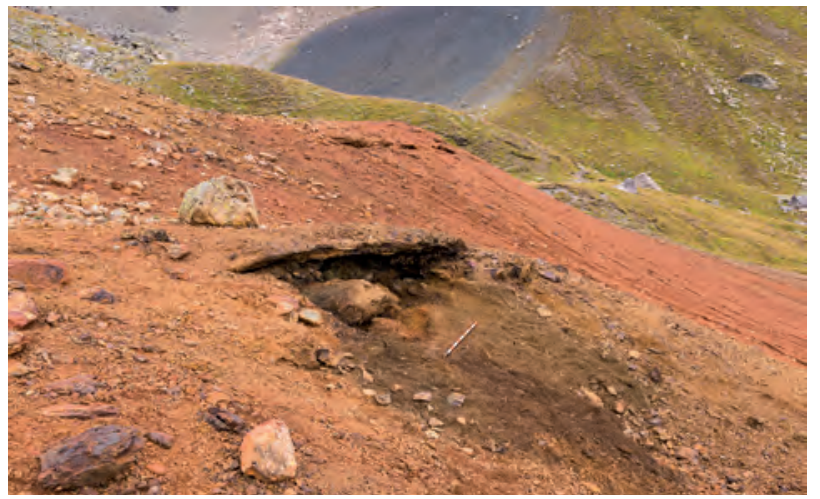

Fig. 5. Avagna-Ochsenalp, area of oldest heap features with solidified ridges, view to southeast. - In foreground: documented sector 1 with heaps II and V (Photo: P. Thomas, DBM).

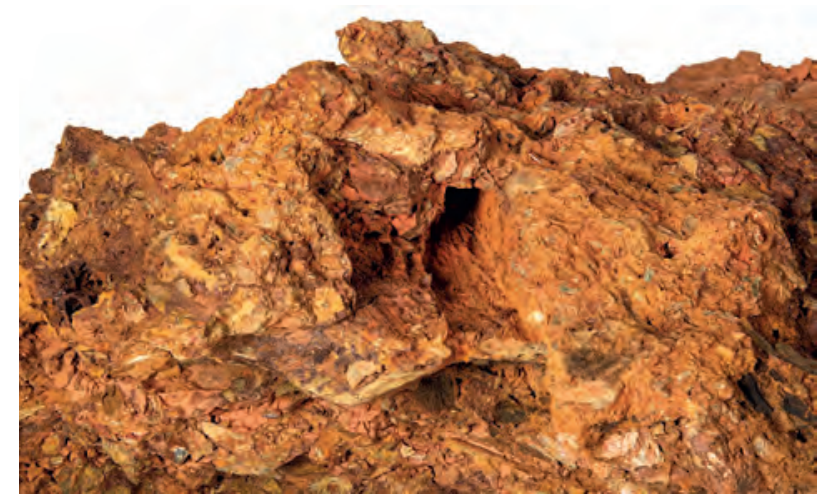

Fig. 6. Avagna-Ochsenalp, negative imprint of two wood shavings (picture centre; width: $4 \mathrm{~mm}$ ) - presumably lighting tapers - from the upper cemented area of heap I (Photo: P. Thomas, DBM).

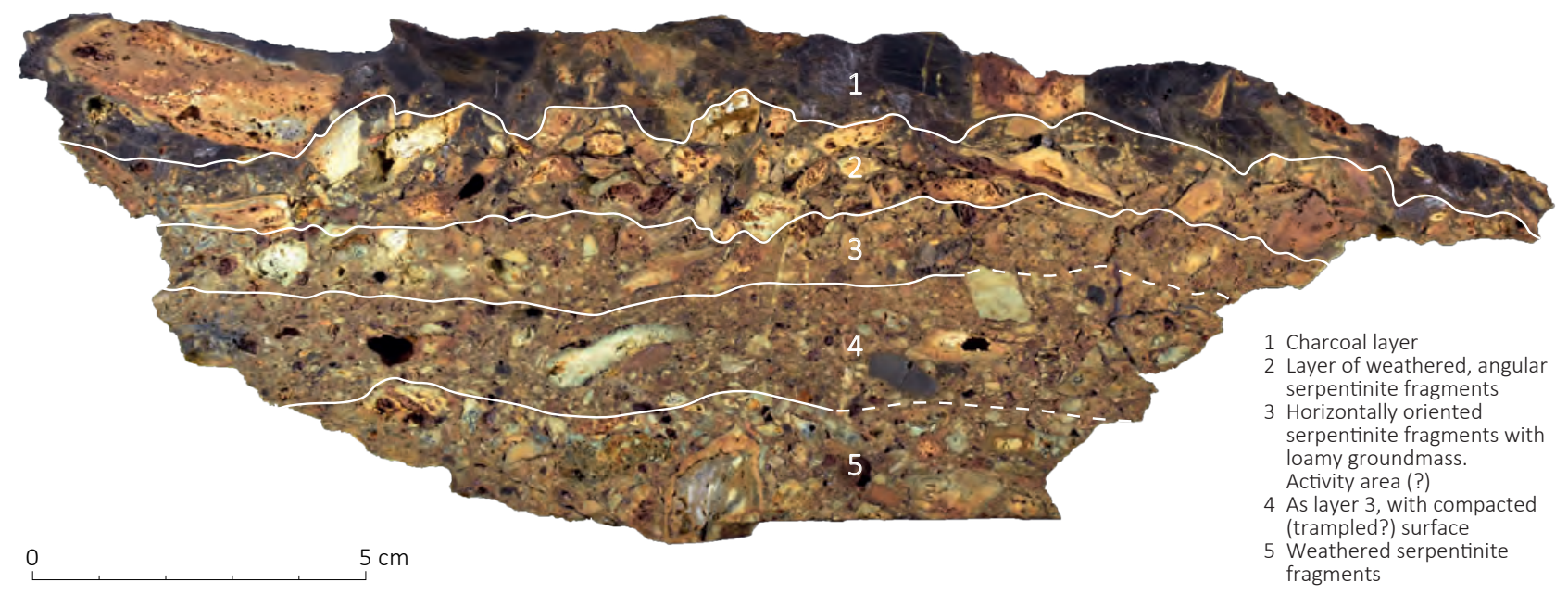

Fig. 7. Avagna-Ochsenalp, polished section of a micromorphological sample from the cemented area of heap I, showing delineated layer boundaries (Photo and illustration: J. Bucher, UZH).

in the form of compacted sediment and horizontally oriented components. ${ }^{17}$ Layer 3 shows similar features and probably represents an activity area.

\subsection{Dating}

Previous research had yielded a Late Bronze Age ${ }^{14} \mathrm{C}$ date for Avagna-Ochsenalp ${ }^{18}$ from a charcoal fragment found in what is apparently a piece of smelting slag. However, an appraisal of the original sample material showed that it was not slag, but a piece of the aforementioned cemented mining

17 RENTZEL et al. 2017.

18 Wyss 1993, 202: B-4188: $2990 \pm 90$ BP; 1433-976 calBC $(2 \sigma)[$ new calibrated]. waste, presumably from an area west of and below the building structure. Three new ${ }^{14} \mathrm{C}$ samples of cemented sediment from heap I (18203.1067-68, 18203.1049.1) also date to the Late Bronze Age (Fig. 8). However, due to the lack of waney edges and sapwood, it is not possible to estimate how accurately these samples date the mining activities. In view of the narrow growth of the tree rings, a single year as well as even entire centuries could be missing.

Newer samples of the mining waste from heap II taken for the present study proved more suitable for dendrochronological dating. A mean curve was constructed of a total of 25 charcoal fragments (Fig. 8, 67459.2-9), the end year being 1043 BC. Short sequences were only taken into 


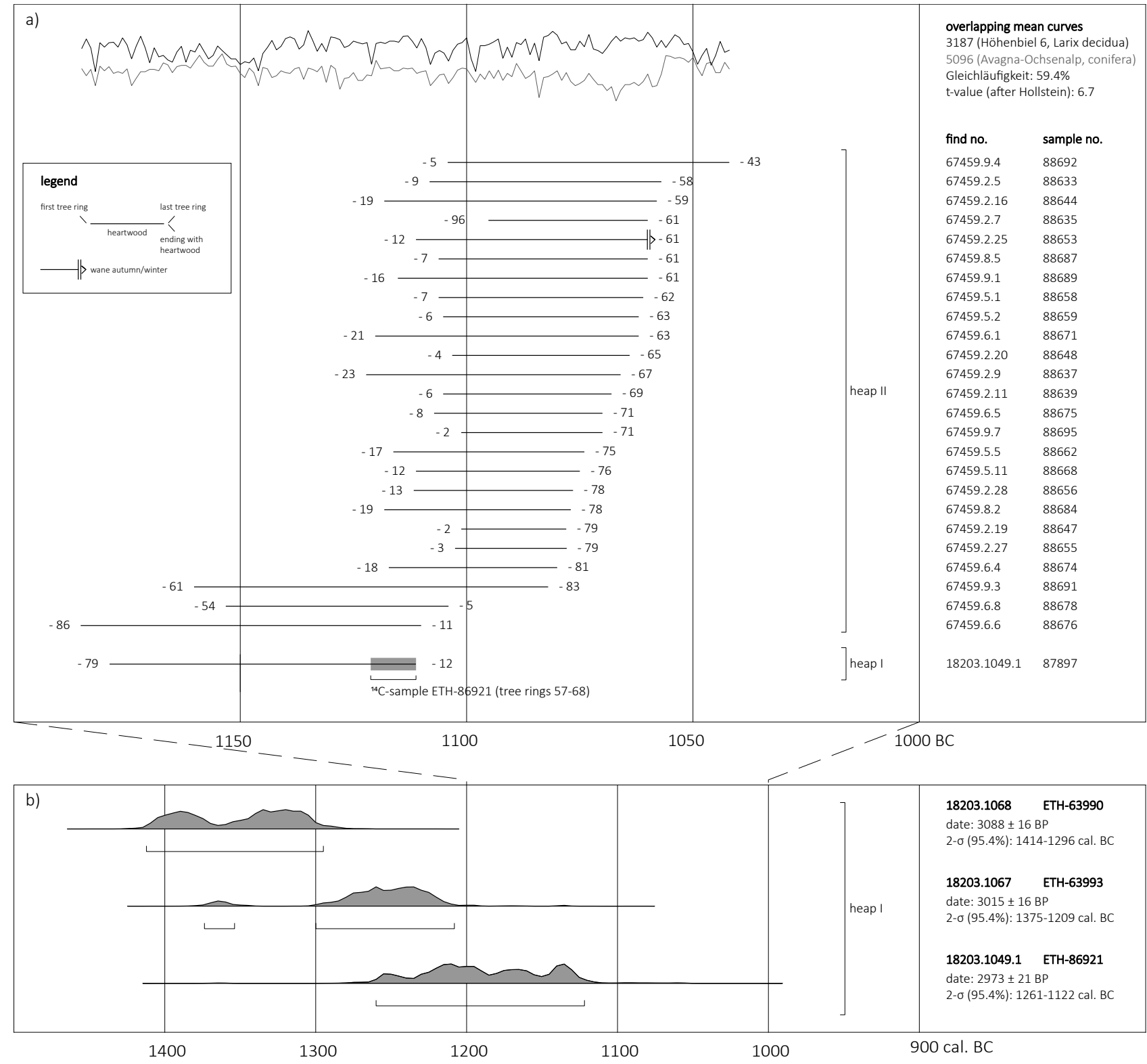

OxCal v4.3.2 Bronk Ramsey (2017); r:5 IntCal13 atmospheric curve (Reimer et al 2013)

Fig. 8. Avagna-Ochsenalp, absolute dates. - a. Cross-correlation and dendrochronological dating of mean curve 5096 and bar chart of all 25 series from heaps I and II. - b. ${ }^{14} \mathrm{C}$ dates of charcoal fragments from heaps I and II (Illustration: L. Reitmaier-Naef, UZH).

account if other samples from the same layer had more than 50 tree rings. Waney edges are generally difficult to detect in charcoal fragments; experience has shown that within dated sample groups there are sometimes waney edges that are older than the youngest end year, indicating the sporadic use of old wood. ${ }^{19}$ Here, bast remains confirm the only definite waney edges, which dates to the year 1061 BC (Fig. 9).

19 OBERHäNSLI et al. 2019.
However, definitive activity in Avagna can be dated at the earliest to $1043 \mathrm{BC}$, based on the later end year dates.

The dendrochronological date of a charcoal fragment (18203.1049.1) from heap I was gained with the help of a ${ }^{14} \mathrm{C}$ dating to the end year $1112 \mathrm{BC}$ (without a waney edge) (Fig. 8). This series correlates with the samples from heap II. Due to the fact that most of the waney edges are missing, it is chronologically possible, but not absolutely certain, that the heaps are contemporaneous. 


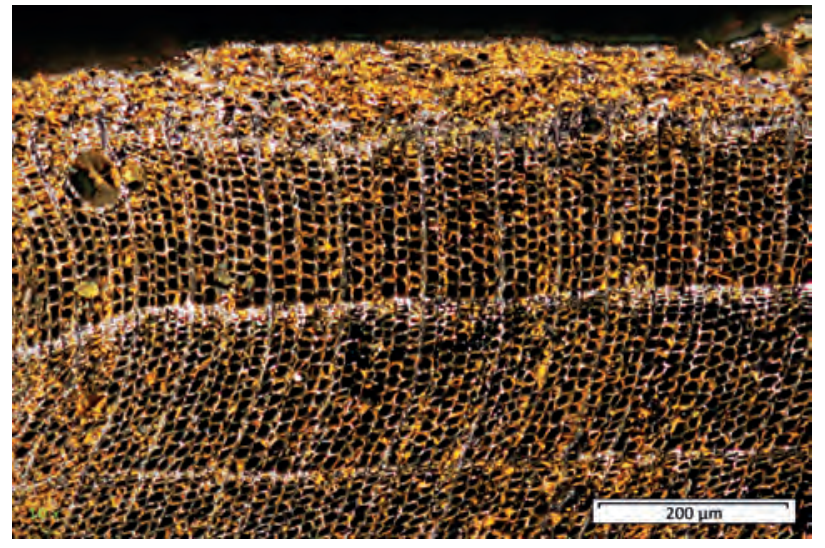

Fig. 9. Avagna-Ochsenalp, sample 67459.2.25 (reflected light): waney edge confirmed by bast remains, dated to $1061 \mathrm{BC}$ (Photo: W. H. Schoch, Laboratory for Ancient Wood Research, Langnau am Albis).

\subsection{Mineralization}

The mineralized outcrop in Avagna is one of the most copper rich mineralizations in the Oberhalbstein region. Because the bedrock of the site is almost completely covered by the heap features, the mineralization is only visible in the terrain to the north of the mining area. It lies roughly horizontally in a heterogenous fault zone in the upper Platta nappe. Two distinct areas can be differentiated within the ore mineralization. The footwall comprises mainly pyrite $\left(\mathrm{FeS}_{2}\right)$ in a chloritic-calcitic matrix, while the hanging wall contains a larger concentration of chalcopyrite $\left(\mathrm{CuFeS}_{2}\right)$ in a mylonitic matrix of chlorite, muscovite and quartz. ${ }^{20} \mathrm{Com}-$ pared with other locations in the Oberhalbstein, the mineralization in Avagna-Ochsenalp is mineralogically relatively simple. The lack of ore minerals such as pyrrhotite $(\mathrm{FeS})$ or magnetite $\left(\mathrm{Fe}_{3} \mathrm{O}_{4}\right)$, which appear regularly in typical serpentinite mineralizations in the Oberhalbstein, is particularly noticeable.

Three ore samples were taken from the northern border of the heap features of Avagna-Ochsenalp, where remains of the mineralization can be found in situ. They represent the two distinct areas of the mineralization (Fig. 10):

1. The samples 4426-AO and 4428-AO both primarily contain pyrite, which is reflected in high $\mathrm{FeO}$ and $\mathrm{S}$ and low $\mathrm{Cu}$ levels in the overall chemistry. In polished sections chalcopyrite has been accordingly observed only in minor amounts, replacing pyrite along fractured edges.

2. In contrast, ore microscopy showed no pyrite in sample 4427-AO. The sample contains only chalcopyrite, as indicated by the corresponding $\mathrm{Cu}$ and $\mathrm{S}$ levels of the analysis. The gangue material of this mineralization is quartz.

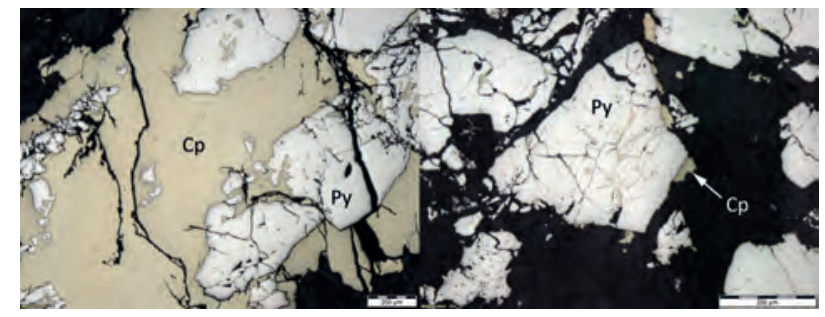

Fig. 10. Avagna-Ochsenalp, cross sections (reflected light). - Ore Sample 4428-AO (left): pyrite (Py), largely replaced by chalcopyrite (Cp). - Ore Sample 4426-AO (right): pyrite with small amounts of chalcopyrite spreading along the fractured edges (Photos: L. Reitmaier-Naef, UZH).

While both mineralizations may have been of interest for the vitriol mines of the modern period, it can be assumed that only copper ore was mined and processed in the prehistoric period. However, it is unclear if or how well both types could be separated during the mining process. The copper produced from this ore cannot be definitively characterized with a single general chemical analysis, but it would be generally low in trace elements and - in contrast to copper from the upper valley step (see section 3.7) - it would not contain high Ni levels (Tabs. 1a-1b).

\subsection{Interpretation}

Written sources attest to mining activity in Avagna-Ochsenalp from the Middle Ages at the latest. Existing radiocarbon data from earlier studies suggested older, prehistoric phases of use, which led to the mining archaeological survey in 2017.

The most prominent features are the multi-phased heaps of the upper section. The evaluation of a detailed digital terrain model allowed at least five separate heaps to be identified, which can be assigned to at least two different operating phases. The two oldest, largest heaps date to the Late Bronze Age. The tops of these heaps have been flattened to plateaus. The sediment on the plateaus is compact and finely layered, which allows an interpretation as a trampling surface. Presumably, these are the peaks that lay directly in front of and functioned as access areas to the mines that are found in the adjoining mining depressions.

The Bronze Age heaps make up the bulk of the features, while the heaps from later activities are less extensive. They lie at the northwestern edge of the terrain and, due to their location and size, can be interpreted as the results of later prospections and clearing-up efforts. The older heaps were partially disturbed or repositioned during these activities. Only the youngest phase can be dated with certainty; due to the use of gunpowder, this phase can be placed in the

20 Dietrich 1972. 


\begin{tabular}{|c|c|c|c|c|c|c|c|c|c|c|c|c|c|c|}
\hline Sample & $\mathrm{SiO}_{2}$ & $\mathrm{TiO}_{2}$ & $\mathrm{Al}_{2} \mathrm{O}_{3}$ & $\mathrm{FeO}$ & $\mathrm{MgO}$ & $\mathrm{MnO}$ & $\mathrm{CaO}$ & $\mathrm{Na}_{2} \mathrm{O}$ & $\mathrm{K}_{2} \mathrm{O}$ & $\mathrm{P}_{2} \mathrm{O}_{5}$ & $\mathrm{~S}$ & $\mathrm{Cu}$ & $\mathrm{ZnO}$ & $\mathrm{Sum}$ \\
\hline $4426-\mathrm{AO}$ & 16,0 & 0,29 & 11,16 & 43,6 & 2,53 & 0,05 & 0,01 & 0,04 & 0,97 & 0,01 & 22,78 & 0,72 & 0,02 & 98 \\
\hline $4427-\mathrm{AO}$ & 57,1 & 0,20 & 5,27 & 14,1 & 2,27 & 0,08 & 0,89 & 0,03 & 0,12 & 1,08 & 3,32 & 3,26 & 0,01 & 88 \\
\hline $4428-\mathrm{AO}$ & 9,5 & 0,10 & 8,11 & 43,8 & 3,26 & 0,04 & 0,01 & $<0,025$ & 0,01 & 0,01 & 26,82 & 0,97 & 0,01 & 93 \\
\hline
\end{tabular}

\begin{tabular}{|c|c|c|c|c|c|c|c|c|c|c|c|c|}
\hline Sample & $\mathrm{Cr}$ & Co & $\mathrm{Ni}$ & $\mathrm{Pb}$ & $\mathrm{U}$ & As & $\mathrm{Sb}$ & $\mathrm{Ag}$ & Se & $\mathrm{Te}$ & $\mathrm{Bi}$ & Sn \\
\hline 4426-AO & 5 & 400 & $<5$ & 1,3 & 2,2 & 70 & 11,1 & $<0,3$ & 15 & 2,3 & 0,2 & 5,7 \\
\hline 4427-AO & 7 & 15 & $<5$ & 70 & 2,0 & 100 & $<0,5$ & 3,8 & 55 & 3,8 & 0,4 & 5,0 \\
\hline 4428-AO & 7 & 1500 & $<5$ & 5 & 2,4 & 15 & 1,4 & 1,0 & 20 & 1,9 & 0,2 & 1,4 \\
\hline
\end{tabular}

Tab. 1. Avagna-Ochsenalp, general chemical analysis (ICP-MS) of ore samples. - a. Major and secondary components in wt.- \%, total in \%. The total iron content was calculated as FeO. - b. Trace elements in ppm. - All samples were measured in the DBM laboratory.

modern period. The older heaps were possibly forepoled during the prospection and clearing up efforts, in order to evaluate the deposit in the bedrock behind them. The collapse of the forepoling after the mine was abandoned resulted in the long depression found on the surface of heap III.

Further structures in the immediate vicinity of the heap features, as well as those in the working area situated at a lower level, cannot be dated with certainty. Only a pestle found below the heaps may be connected to prehistoric copper ore beneficiation.

\section{Cotschens}

\subsection{Mining Site}

The second surveyed area lies on the upper valley step of the Oberhalbstein, west of Lake Marmorera, at the western end of the largest and most important mineralization zone of the region. The mineralization extends roughly along the present-day dam wall to the Gruba mining area on the eastern side of the valley and crops out at various points. It is not surprising, then, that the former plain of Marmorera contains the highest number of verifiable prehistoric smelting sites. Beside the prehistoric mines Vals (Marmorera GR) and Gruba II (Marmorera GR), which have been the subjects of earlier studies, ${ }^{21}$ the previously unstudied mining area Cotschens seemed a likely source of materials for prehistoric copper production, ${ }^{22}$ particularly in light of the lack of written and archaeological evidence of medieval or modern mining activity.

The area, which lies at 2130-2300 masl, extends over an Alpine pasture and slopes to the east, with a total extent of over $0.1 \mathrm{~km}^{2}$. From east to west, the following areas along the ascending slope can be distinguished (Fig. 11):

21 Reitmaier-Naef, Turck, Della Casa 2015. - Turck et al. 2018. 22 E.g. SCHAER 2003.

\section{Val Starschagns}

There are several working traces in the area of the upper escarpment of Val Starschagns. A small mine is situated directly below the escarpment. It comprises two parallel, slightly sloped adits of around 10-15 $\mathrm{m}$ in length. The working face of the northern structure is flooded, and a heap of fine material anterior to this suggests underground processing activity. To the south of the mine, a depression filled with coarse rubble suggests a further underground part, which is now almost completely collapsed.

Slightly to the northwest of this area, directly above the escarpment of Val Starschagns, a flat mining depression of $30 \mathrm{~m}$ in length runs from east-southeast to west-northwest, accompanied almost continuously along the east-northeast by a heap. Further mining activity, presumably younger, is evident at both ends and seems to align with the course of the mining depression.

To the south of this, a $12 \mathrm{~m}$-long trench which strikes southeast to northwest runs towards the mining depression at an acute angle. Small drifts that follow the line of strike of the mining depression can be found at the northwestern end. Downslope, this depression is almost entirely surrounded by a contiguous heap.

\section{Area S}

An ore outcrop lies around $150 \mathrm{~m}$ to the southwest, further up the slope. It is primarily marked by a heap of roughly $35 \mathrm{~m}$ in diameter. Both the bedrock and the heap material show the rust-red colouring that is characteristic for Cotschens. Detailed archaeological examinations are still pending, but various features in the terrain, such as a ramplike structure south of the heap, could indicate more extensive mining activity. 


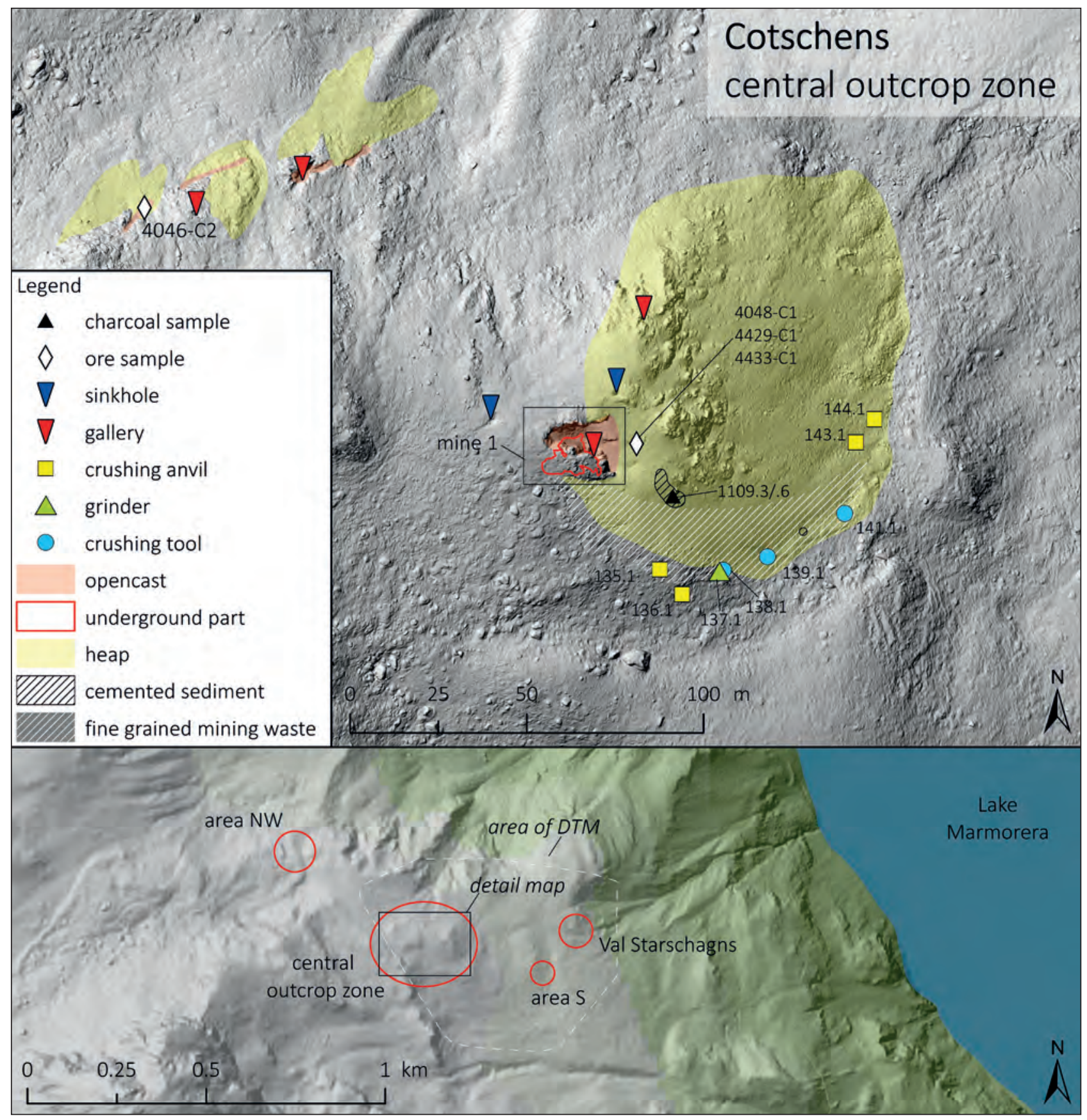

Fig. 11. Cotschens, maps of the mines, heaps, finds (18203.[...]), charcoal samples (18203.[...]) and ore samples (Map: L. Reitmaier-Naef, UZH; terrain model: A. Zwicky and Ch. Walser, ADG; geodata: Federal Office of Topography and Canton of Grisons).

\section{Central Outcrop Zone}

The largest area of activity lies at a central position in the terrain and is visible from afar due to its extensive, strikingly red mining waste heaps. This colour is eponymous for the entire mining area of Cotschens (cotschen, Romansh: red). The area is divided into an eastern and a western part, the eastern part being more productive in terms of mining archaeology. Here, the outcrop zone extends over an area of $70 \times 65 \mathrm{~m}$. A heap measuring $120 \times 60 \mathrm{~m}$ lies in front of this to the east. Mine 1, which was archaeologically surveyed in the summer of 2017, is situated in this area. At least two collapsed portals, a sinkhole directly northeast of mine 1 and a similar depression $16 \mathrm{~m}$ to the west of the mine all indicate further underground mining activity. Cemented sediment, 
which contains numerous fragments of wood and charcoal, is found around the heap, especially southeast of mine 1 . The upper and middle part of the southern side of the heap contains comparatively fine material. Based on the stone tools found here, this area could be interpreted as a processing site, which is a unique find so far in the Oberhalbstein region (Fig. 11).

In the western part of the area, the outcrop stretches over $120 \times 60 \mathrm{~m}$. Heaps are found mainly to the northeast and to a lesser extent to the northwest. Traces of mining are found here mainly as mining depressions and trenches that follow diabase dykes which strike from northeast to southwest (Fig. 12), as well as isolated collapsed portals which seem to follow the direction of the dykes. Finally, at the northwestern edge of the outcrop, there are several small test trenches.

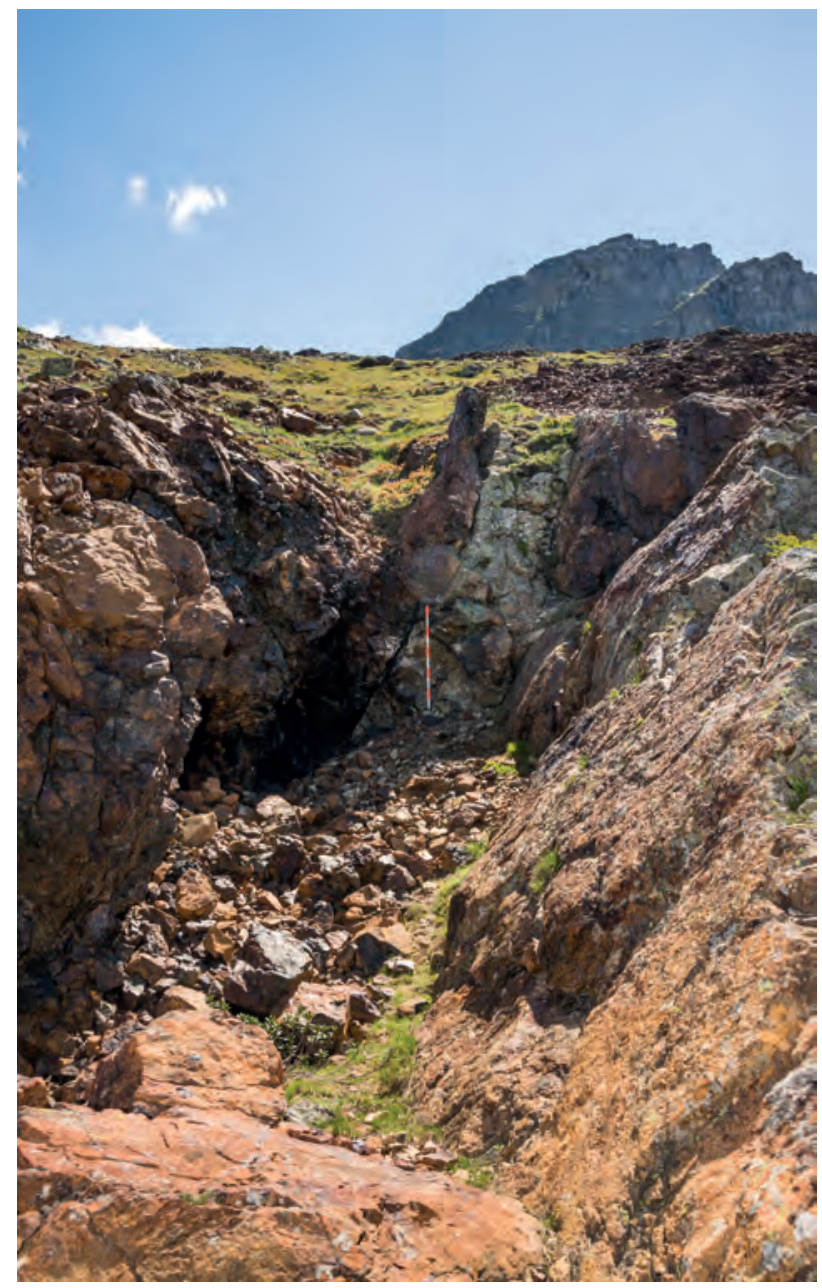

Fig. 12. Cotschens, view of an undated mining trench in the north-western area of the central outcrop zone, which follows a diabase dike (pale stone, center of image). View to southwest (Photo: P. Thomas, DBM).

\section{Area NW}

A smaller, previously completely unknown mining area lies roughly $250 \mathrm{~m}$ northwest of the central outcrop zone. It comprises several features: an elongated trench runs west-southwest to east-northeast over approximately $30 \mathrm{~m}$, an approximately $65 \times 20 \mathrm{~m}$ heap of noticeably fine-grained material adjoins the trench to the north, and a small but pronounced southwest-northeast striking trench, which consists of three mining depressions of up to $10 \mathrm{~m}$ in size is situated in the eastern part of the area.

\subsection{Description of Mine 1}

The mine is situated at the southern edge of the eastern part of the central outcrop zone. It consists of two main parts: an elongated opencast and an underground part which adjoins to the south.

The opencast strikes in an east-west direction for around $20 \mathrm{~m}$ (Fig. 13). Its widest point of $12 \mathrm{~m}$ lies at the eastern, down-slope end. As it extends up the slope, it narrows to around $6 \mathrm{~m}$ and ends in a working face that is around $3 \mathrm{~m}$ high. The northern side wall also has a height of around $3 \mathrm{~m}$ and inclines noticeably to the south, especially in the back, western end of the opencast. At the eastern end, the wall is set more to the north over a length of $5 \mathrm{~m}$, and slightly undercut. The southern side wall is slightly higher than its northern counterpart. However, because the infill of the opencast slopes to the south, the southern side wall rises significantly higher and reaches a height of up to $5 \mathrm{~m}$. It is almost vertical and in places also slightly undercut.

Due to the fissured rock, the surfaces of the side walls are very irregular, making traces of mining work difficult to detect. Rounded forms have only been preserved in a few places in the harder areas of the rock, especially on the south wall and on the western working face.

The opencast mine is partially filled with rubble, which covers the entire floor of the mine. The sediment generally inclines to the east and south. In the eastern area, several boulders protrude from the sediment; some are collapsed blocks, while others seem to be part of the bedrock. This also seems to be the case for a low step that runs through the middle of the mine, following the line of strike. A massive rock spur to the southwest of this forms a northeast-southwest wall, which only shows traces of deep incisions at its southwestern end and is thus separated from the southern wall of the mine. On its southeastern side, a rounded mining feature undercuts the spur in a western direction. However, the full extent of this feature cannot be determined due to the infill.

In the area surrounded by the described structures, the surface of the infill is markedly lower than in the rest of the 
opencast, the difference in height reaching up to $3 \mathrm{~m}$ in some areas. The entrance to the underground part of the mine is situated here, lying at the foot of the south wall and opening to the southwest.

The entrance to the underground part from the opencast is around $9 \mathrm{~m}$ wide. Most of this, however, is filled with rubble which has entered the mine from the opencast. Access to the mine is only possible from the east, where the infill is lower.

The underground part of the mine inclines by $20^{\circ}$ to the west-southwest and has a length of $17 \mathrm{~m}$. The total height is around $8 \mathrm{~m}$, and the maximum width reaches $12 \mathrm{~m}$ in the line of strike (Fig. 14). The mine comprises several domed working sections which intersect and are arranged in a linear fashion along the incline. At least three such structures can be differentiated. Their roofs are domed, but the walls are partially segmented into smaller structures with further domes and recesses, most prominently in the central area of the south wall of the mine. Two structures which seem to differ from this principle extend the mine to the north. A small drift is situated at the mine's lowest point and extends from the north wall for around $1.5 \mathrm{~m}$ to the north. While the cross section is rounded, the ground plan is clearly rectangular. A larger drift in the upper section of the mine shows similar characteristics. This drift extends over $4 \mathrm{~m}$ to the northwest. It is considerably larger, with a width of around $4 \mathrm{~m}$ and a height of over $4 \mathrm{~m}$. Straight walls and an irregular profile suggest that a different mining technique was used here.

Large parts of the floor of the mine are covered with rubble, making it difficult to completely determine its southern extent. Only the lowest stope and the two drifts which extend to the north are free of sediment (Fig. 15). Beginning at the opencast mine, the infill slopes steeply to the southwest, south and southeast. Rough rubble is concentrated at the foot of the incline, while the material in the upper part of the mine is finer. Two large rocks found here in the infill are presumably collapsed blocks from the roof of the mine.

\subsection{Description of the Findings in Mine 1}

In order to study the infill in the opencast, a test trench measuring $80 \times 80 \mathrm{~cm}$ was opened directly at the base of the southern wall (Fig. 13, sector 1). From just a few centimetres below the surface, the bedrock below is relatively flat, sloping only slightly to the east, indicating that the infill may not be very thick in the southwest part of the opencast. It consists of heterogeneously distributed, partly sub-horizontally stratified serpentinite rubble (mainly $0.5-10 \mathrm{~cm}$ ). The components are strongly weathered and cemented to a hard, breccia-like deposit. At a depth of around $30 \mathrm{~cm}$, especially in the area of the walls, the material is so solidified that it is almost impossible to remove it manually.

The underground part of mine 1 is currently flooded; water fills the entire lower area of the stope. The flooding contributed to the good preservation of the wooden objects. After the stope had been drained, a layer of mud a few centimetres thick remained. Most of the wooden artefacts were found in this layer. Many of them were probably moved by the water and date from different periods of use. A trough, of which more than half was preserved (Figs. 16, $18,67457.22 .1)$ was found on the floor of the small drift in the northern wall.

In a small, raised recess in the southern wall of the lower stope, sediment was preserved between the mud layer and the bedrock. This was excavated manually and documented (Fig. 14, sector 2). The up to $5 \mathrm{~cm}$-thick sediment consisted of partially oxidized, fine angular rock fragments. This layer also contained several charcoal fragments and further wooden artefacts, including a spatula (Fig. 18, 67457.38.1) in situ.

The largest outcrop is situated in the upper area of the mine, between the portal and the northern wall (Fig. 14, sector 3). From here, the infill inclines sharply from the roof to the southwest into the mine. The loose rubble on the surface, presumably originating from the opencast, was removed from an area of approximately $3.5 \times 3.5 \mathrm{~m}$ (sloping over a height of almost $4 \mathrm{~m}$ ). Several layers of older filling, levels with evidence of burning and stone structures were revealed beneath. The layers, partially cemented due to secondary oxidization, had been almost vertically truncated even before they were covered by the loose material. They were generally left as found, which is why the documented profile is stepped.

These layers are aligned horizontally south-north and cover the floor in the northern part of the mine (Fig. 17). Three to four thick layers of rough infill, separated by thin sediment layers containing fine charcoal, make up the lower half. Two of these thin charcoal layers are visibly reddened by exposure to heat in their lower area. Two charred animal bones were found in the uppermost layer of the two. The roughly layered infill consists of sharp-edged serpentinite rubble of varying sizes $(0.5-30 \mathrm{~cm})$ and proportions. The coarse-grained, porous infill generally seems to be more cemented than the finer material. The deposit has a reddish-brown to violet-black colour and shows a glossy surface in the cemented areas. Polished sections show that the dark-green serpentinite and especially the ore-bearing veins are heavily weathered, leading to a porous structure or a peripheral weathering zone. At least one fragment is completely coloured red, presumably due to exposure to 


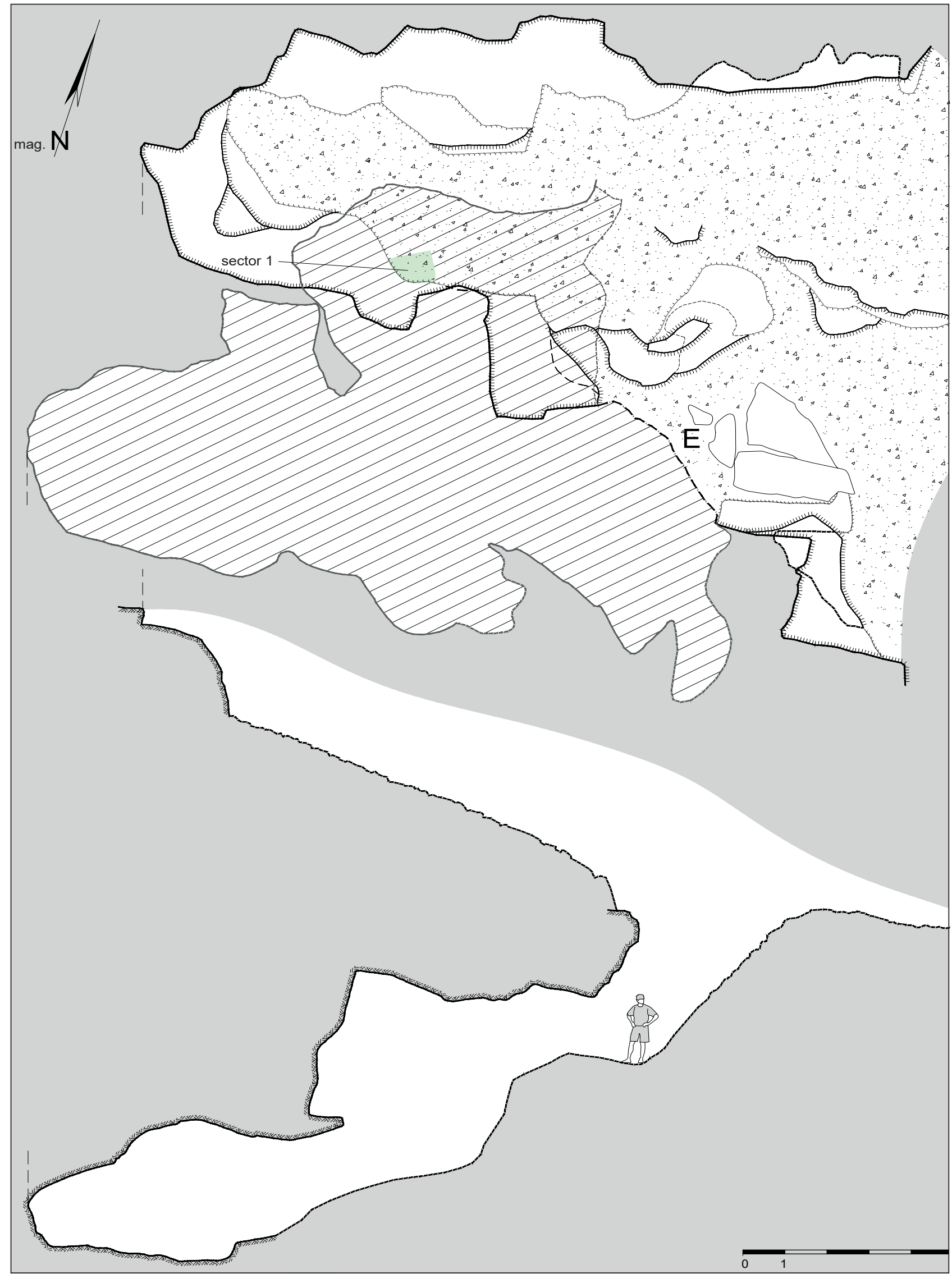

Fig. 13. Cotschens, mine 1, opencast with underground cavity. - Top: ground plan. - Bottom: vertical projection (Plan: P. Thomas and G. Steffens, DBM). 


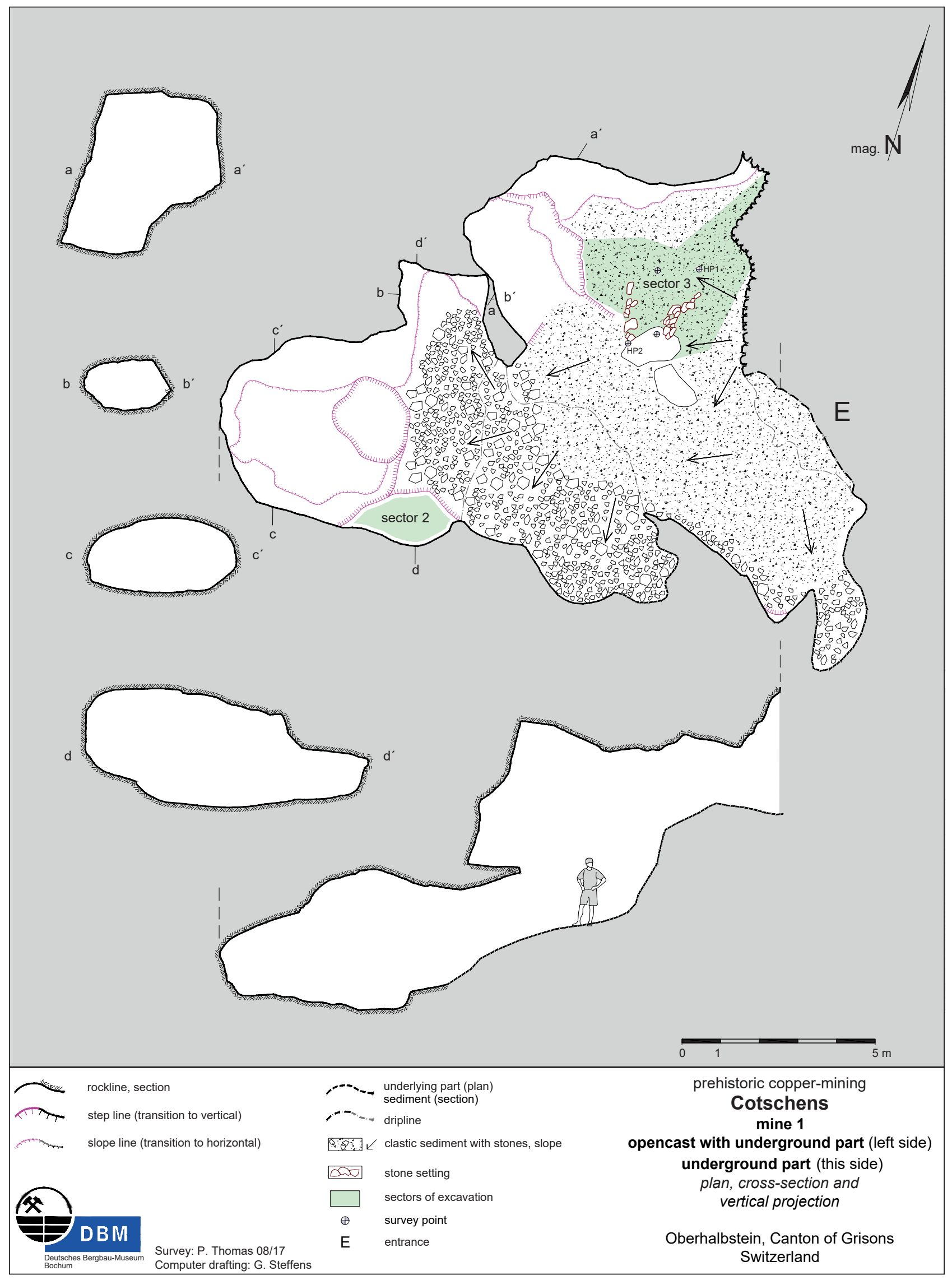

Fig. 14. Cotschens, mine 1, underground part with cross sections and vertical projection (Plan: P. Thomas and G. Steffens, DBM). 


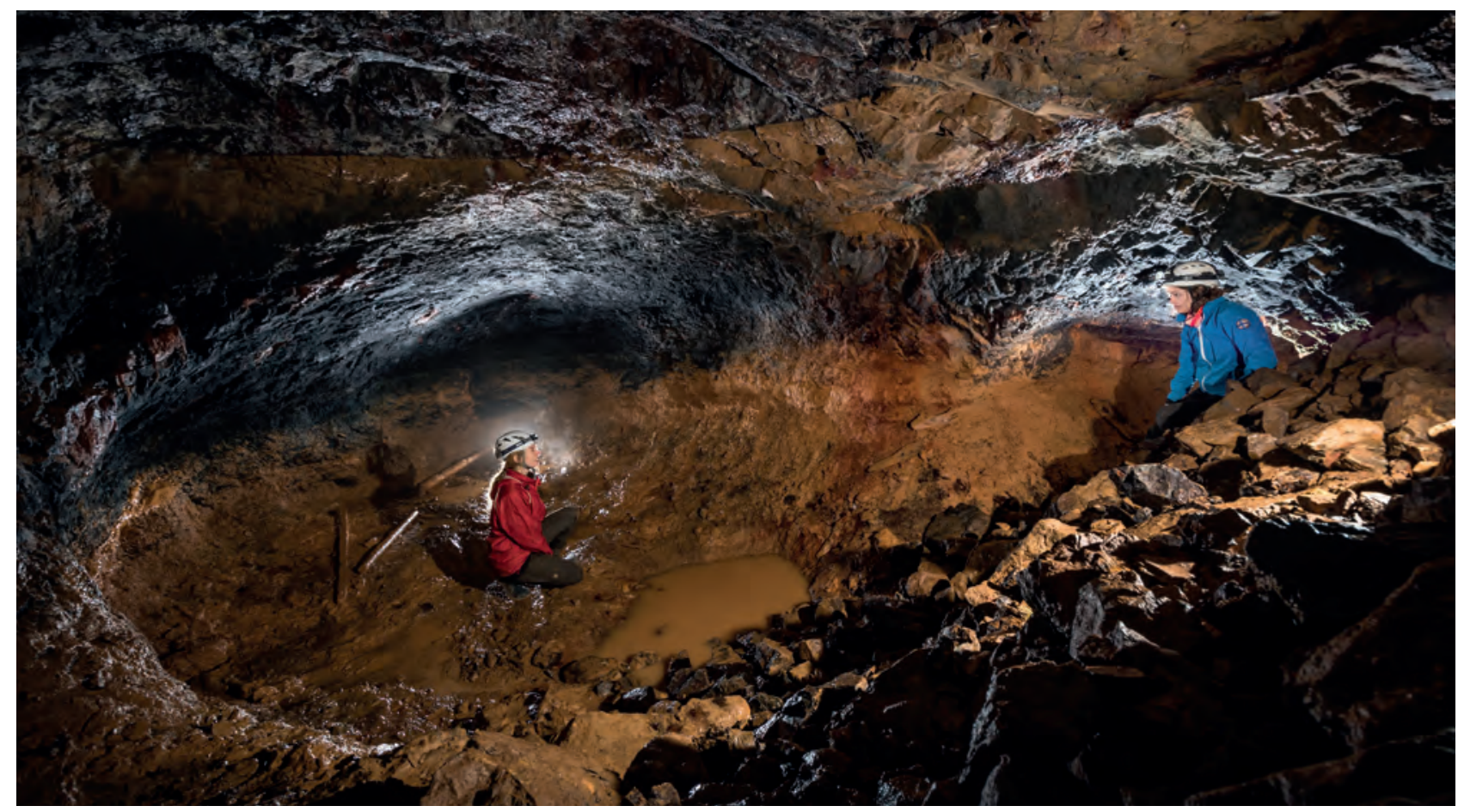

Fig. 15. Cotschens, mine 1, lowest stope area with wood finds and small northern drift, view to the west (Photo: P. Thomas, DBM).

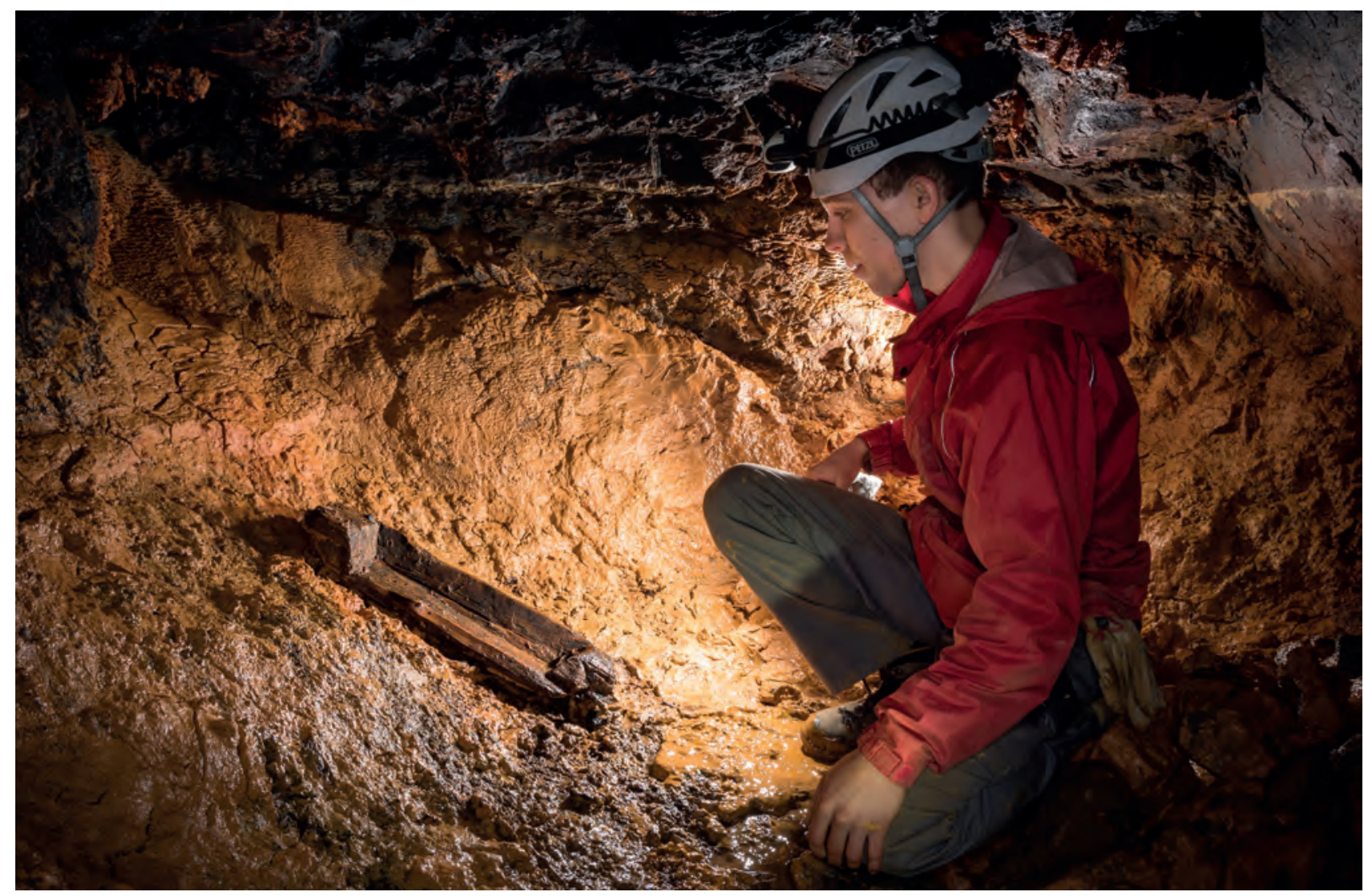

Fig. 16. Cotschens, mine 1, one of the La Tène period troughs (67457.22.1) in its original position on the floor of the small drift in the northern side wall of the lowest stope area (Photo: P. Thomas, DBM). 


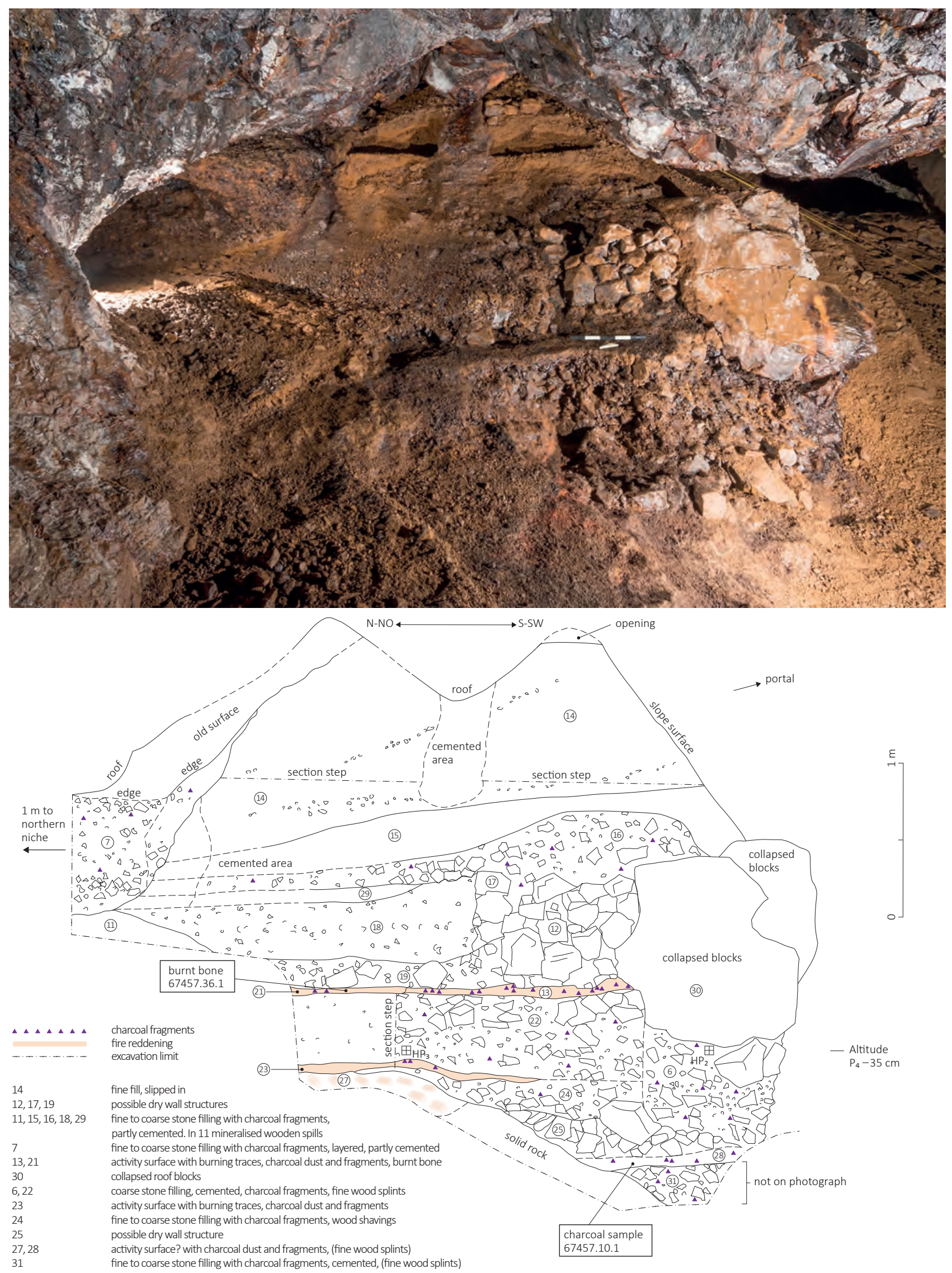

Fig. 17. Cotschens, mine 1, sector 3, east section (Photo: P. Thomas, DBM; drawing: J. Bucher, UZH and M. Huwiler, ADG). 
intense heat. The locally abundant charcoal fragments, as well as the smaller wood shavings, are mostly either partially or completely impregnated by iron precipitations.

The two large boulders, which presumably stem from the roof of the mine, lie on top of the three lowest infill layers. The uppermost burned layer abuts these blocks, indicating that the collapse took place while the mine was in use.

The stone structures in sector 3 may be walls constructed as the western border of the infill of the east section. The structures cannot be stratigraphically placed with certainty and may belong to a younger phase of mining activity. The infill layers in the western area of the documented profile may have slipped away or been removed in this phase.

\subsection{Wood Objects}

A total of 66 wood objects were found in mine 1 in Cotschens, 50 of which have been worked. Both the excellent preservation of the objects and the partial traces of washing out are due to the waterlogged preservation conditions.

While the purpose of 14 of the objects is unclear, the remaining 36 artefacts could be assigned to ten object groups (Tab. 2). These include three modern artefacts: a machine-produced, burned matchstick (67457.35.3), which dates to the $19^{\text {th }}$ century at the earliest, ${ }^{23}$ a red and white painted snow pole (67457.13.1) and a roof batten (67457.12.1).

The determination of the wood species revealed that - apart from the matchstick, which was made of poplar (Populus) - the objects were made of Scots pine or mountain pine (Pinus sylvestris or mugo Turra), Swiss stone pine (Pinus cembra) or spruce (Picea abies)/larch (Larix decidua). While the larch and spruce are particularly suitable for stable constructions and robust tools, the Swiss stone pine and the mountain pine are softer conifer species that are suitable as firewood. Grouping these 36 artefacts according to function-specific ideal properties, even this small sample size showed a tendency towards an intentional choice of wood, which takes into account the suitability of hard wood for tools or soft wood as firewood.

The most significant finds will be discussed below.

Fragments of two troughs (Fig. 18, 67457.22.1; 67457.28.1) dated to the La Tène period (see section 3.6 and Fig. 20) are among the most spectacular finds. The larger of these fragments can be described in more detail. The preserved segment, made of a half section, has a reconstructed width of $22 \mathrm{~cm}$ and a length of $51.8 \mathrm{~cm}$. A segment was removed tangentially from the bottom to form a base. The end faces are inclined slightly outward and short handles have been worked out of their upper edges. A cavity was worked into the upper side which is trapezoidal in both longitudinal and cross section. Traces of manufacturing are only found on the inner end sides and floor. The toolmarks, visible due to the excellent state of preservation of these parts, indicates the use of a single axe..$^{24}$ Most of one longitudinal half of the trough is missing from its present form, having broken off along a longitudinal fracture. A similar fracture runs along the intact side wall. The second preserved fragment is the handle of another, presumably slightly smaller trough.

A shovel-like tool (Fig. 18, 67457.9.1) with a maximum width of $8.4 \mathrm{~cm}$ and a length of $52.7 \mathrm{~cm}$, which was carved from a log, also dates to the La Tène period. The handle, almost round in cross section and roughly worked at the end, merges smoothly with the narrow blade. The blade constitutes approximately two thirds of the length of the tool and is flattened on the underside and only slightly concave on the upper side. Large-scale charring appears in the area of the hollow. Traces of manufacture are mainly found around the handle. In addition, the underside of the tool shows extensive marking, with 165 vertical tool or chopping marks.

The spatula (Fig. 18, 67457.38.1) dating to the Hallstatt period was carved from a radially split piece of wood and has a flat cross section and longitudinal section. The preserved length of $27.8 \mathrm{~cm}$ almost entirely comprises the elongated blade, which transitions smoothly to the stub of the broken handle. The surface is slightly washed out, making it impossible to see potential traces of use on the long and broad sides.

An undated fragment of an object of unknown purpose (Fig. 18, 67457.14.1/15.1/23.1) shows noticeably careful shaping and working around the edge, despite poor surface preservation.

Seven lighting tapers and wedges with charred ends, of different shapes and dimensions and made of both branch and trunk wood, were also found in Cotschens. Only one lighting taper (67457.35.2) - dating from the modern period -is known to be fully preserved. Axe marks that have clearly cut the shaft are visible at the end of the taper. The other lighting tapers show signs of breaking or erosion at the ends. In addition, nine contorted, charred wooden objects were assigned to a group of objects of unknown function. They were presumably used for timbering or as firewood. Three wedges, a fragment of a shaft and four wood shavings were also found. The latter in particular can be seen as waste from the woodworking process. 


\begin{tabular}{|c|c|c|c|c|c|}
\hline Categories & Object groups (number of objects) & $\begin{array}{l}\text { Larix decidua/ } \\
\text { Picea abies }\end{array}$ & Pinus cembra & $\begin{array}{l}\text { Pinus sylvestris/ } \\
\text { mugo Turra }\end{array}$ & Populus \\
\hline \multirow[t]{5}{*}{ Tools } & Shovel-like tool (1) & & 1 & & \\
\hline & Spatula (1) & 1 & & & \\
\hline & Troughs (2) & 1 & 1 & & \\
\hline & Shaft (1) & 1 & & & \\
\hline & Wedges (3) & 1 & 1 & 1 & \\
\hline Manufacturing waste & Wood shavings (4) & 4 & & & \\
\hline Lighting & Lighting tapers (7) & 1 & 1 & 5 & \\
\hline \multirow[t]{2}{*}{ Building/firewood } & Split wood with charred ends (4) & 2 & 1 & 1 & \\
\hline & Contorted, charred wood artefacts (9) & 1 & 5 & 3 & \\
\hline Tally stick & Tally stick (1) & 1 & & & \\
\hline Unknown & Unknown (14) & 8 & 3 & 3 & \\
\hline \multirow[t]{4}{*}{ Modern artefacts } & Match stick (1) & & & & 1 \\
\hline & Roof batten (1) & 1 & & & \\
\hline & Snow pole (1) & 1 & & & \\
\hline & Total & 23 & 13 & 13 & 1 \\
\hline
\end{tabular}

Tab. 2. Cotschens, mine 1, distribution of wood artefacts by object groups.

A fragment of notched wood (Fig. 18, 67457.30.1) showing symbols carved with a knife dates to the early modern period.

The spectrum of prehistoric wood artefacts found in Cotschens corresponds well with mining finds from other periods. Troughs similar in all characteristic details to those found in Cotschens appear in earlier, Bronze Age contexts, and can be traced almost unchanged to the modern period. These vessels are ore or mining troughs, used to transport extracted ore or mining waste..$^{25}$ The same applies to the spatula-like tools. While these are also found in settlement contexts, ${ }^{26}$ some examples have been found in Alpine mining contexts, where they are associated with the haulage and the beneficiation of ore. ${ }^{27}$ Shovels are also a part of the standard repertoire of mining tools for both prehistoric and later mines, ${ }^{28}$ although the artefact from Cotschens is distinct due to its clumsy design. It is possible that it was made as an ad boc tool. Similar objects were deposited in large numbers on the Schöllberg-Göge in South Tyrol, presumably as part of a ritual act. ${ }^{29}$ The charring on the blade of this fragment, however, corresponds with other Alpine mining finds that

25 Thomas 2018.

26 E.g. Perini 1987.

27 Goldenberg et al. 2011. - Stöllner et al. 2012. - Koch WaldNER 2017. - Thomas 2018.

28 Thomas 2018.

29 STEINER et al. 2009. - STEINER 2010. show similar patterns of charring. This may indicate the use of these shovels to carry embers. ${ }^{30}$ The notched wood can be interpreted as a tally stick. These objects were used in some areas into the $20^{\text {th }}$ century, and recorded house signs, ownership status or the calculations of shepherds, Alpine dairymen and farmers with carvings and decorations that ranged from simple to elaborate. ${ }^{31}$

\subsection{Stone Objects}

An assemblage of stone artefacts that fit well into the spectrum of prehistoric ore beneficiation tools ${ }^{32}$ was found in the area of the heap south of the mine: several hand-held crushing tools or pestles, anvil stones and the fragment of a grinder (Fig. 19).

Two of the pestles are preserved completely (Fig. 19, 13203.138.1/139.1), while the third is fragmented (18203.141.1). Gneiss which probably originates in the Julier crystalline was used to craft two of these tools, while the third is made from local serpentinite. The rough stones were artificially worked into flattened spherical to discoid shapes. Their diameter is between 8 and $11 \mathrm{~cm}$, the weight of the complete pestles between 600 and $700 \mathrm{~g}$. Only half of the fragmented pestle has survived. This fragment alone weighs

\footnotetext{
30 See Thomas 2018.

31 STebler 1907. - Weiss 1941.

32 Stöllner et al. 2012. - Timberlake 2014.
} 

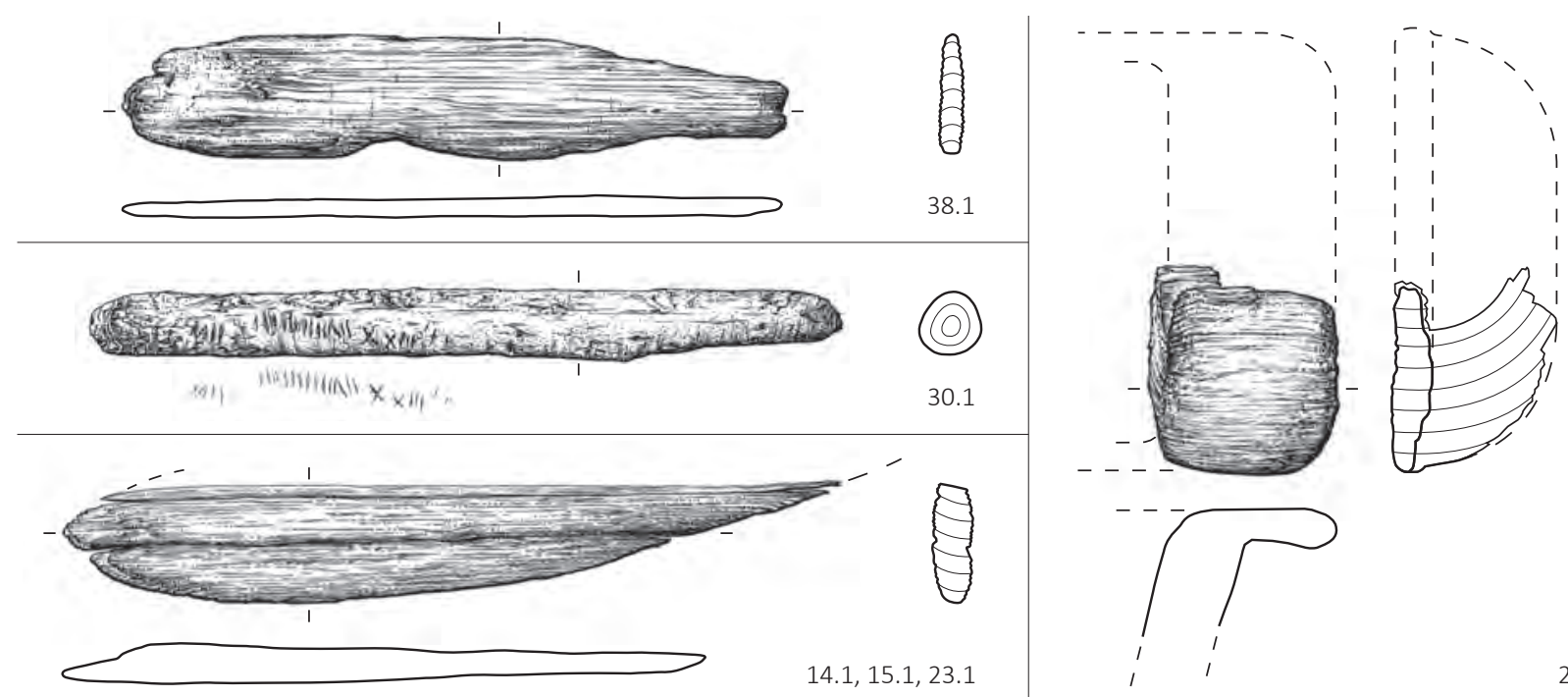

28.1

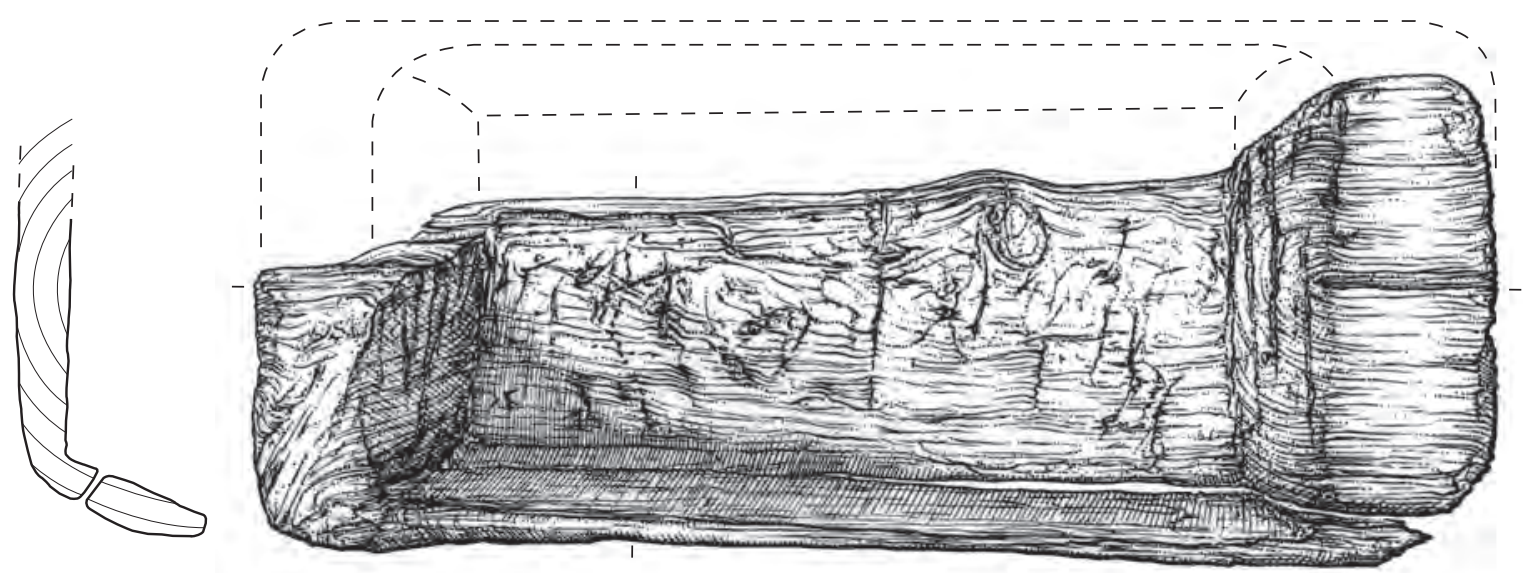

22.1
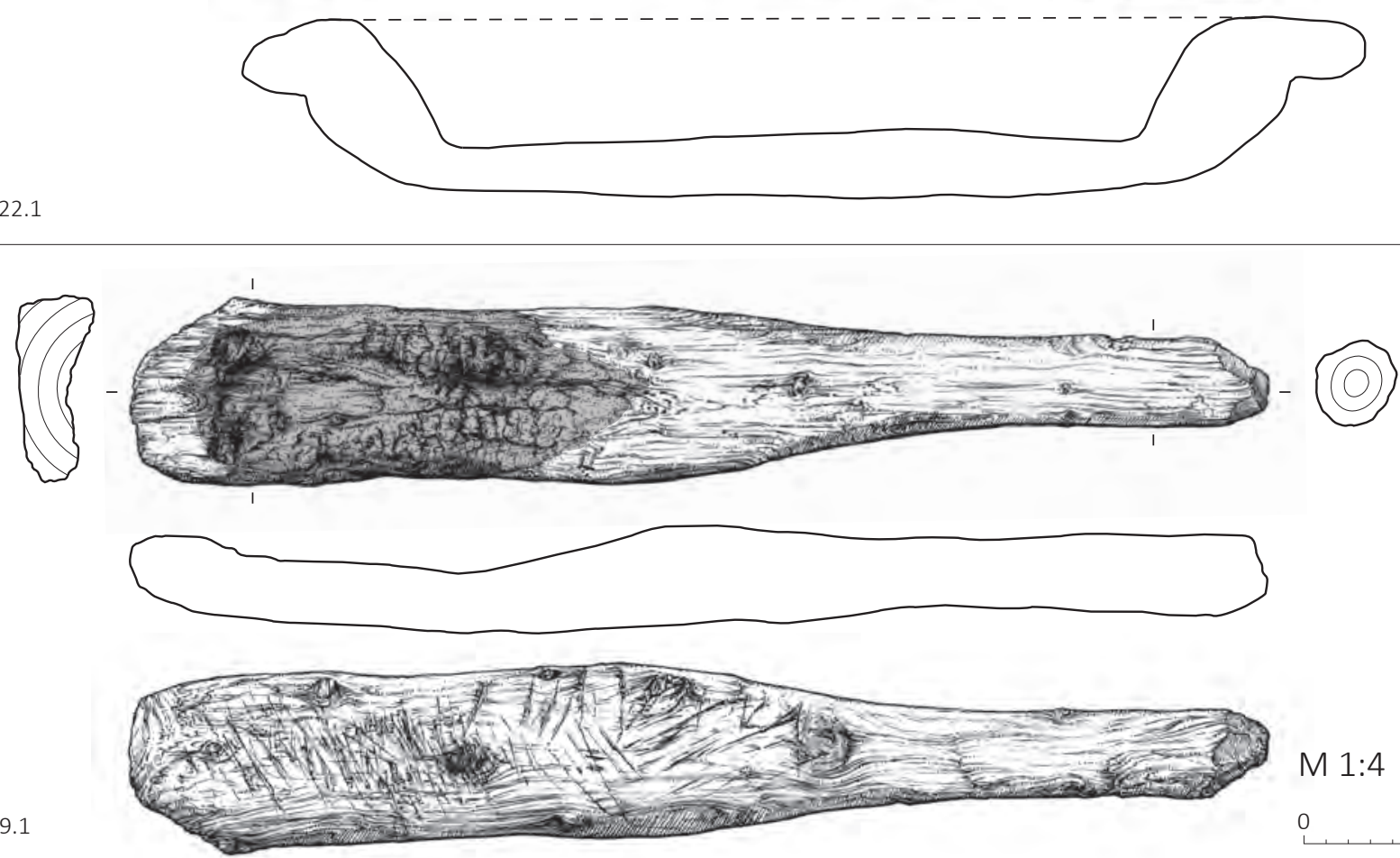

M 1:4

9.1

Fig. 18. Cotschens, mine 1, wood artefacts: spatula (67457.38.1), tally stick (67457.30.1), unknown objects (reconstructed from three fragments 67457.14.1/15.1/23.1), trough fragment (67457.28.1), trough (67457.22.1), shovel-like tool (67457.9.1) (Illustration: L. Gredig, ADG). 


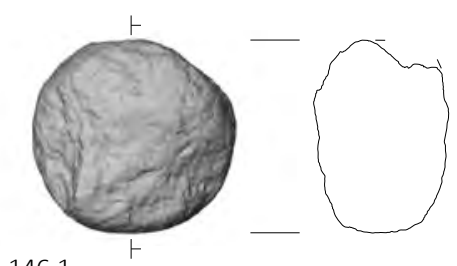

146.1

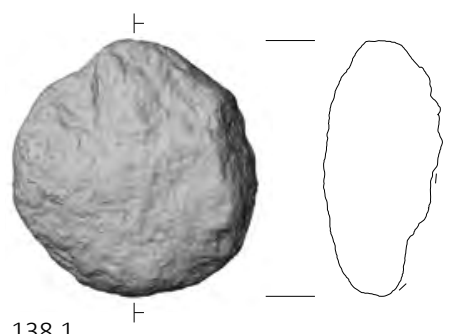

138.1

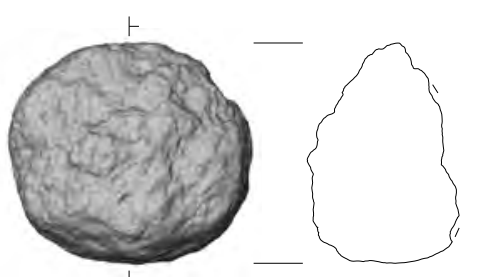

139.1
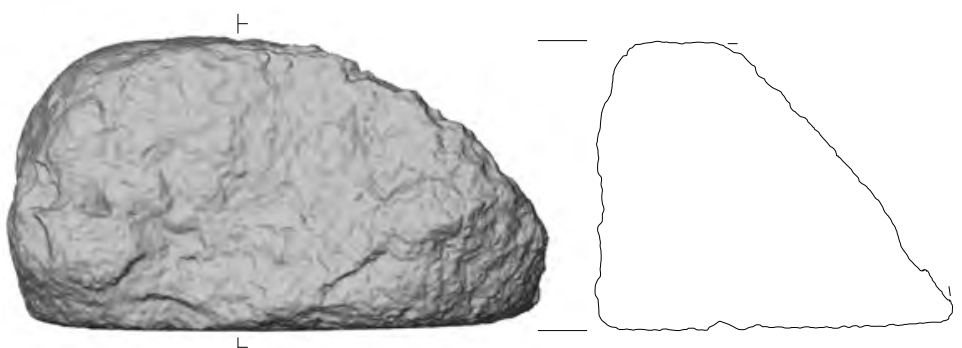

137.1

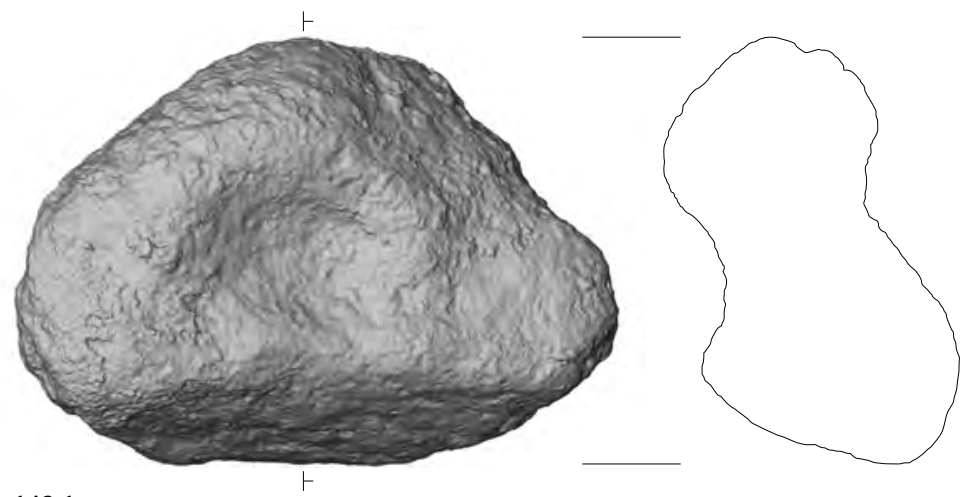

142.1
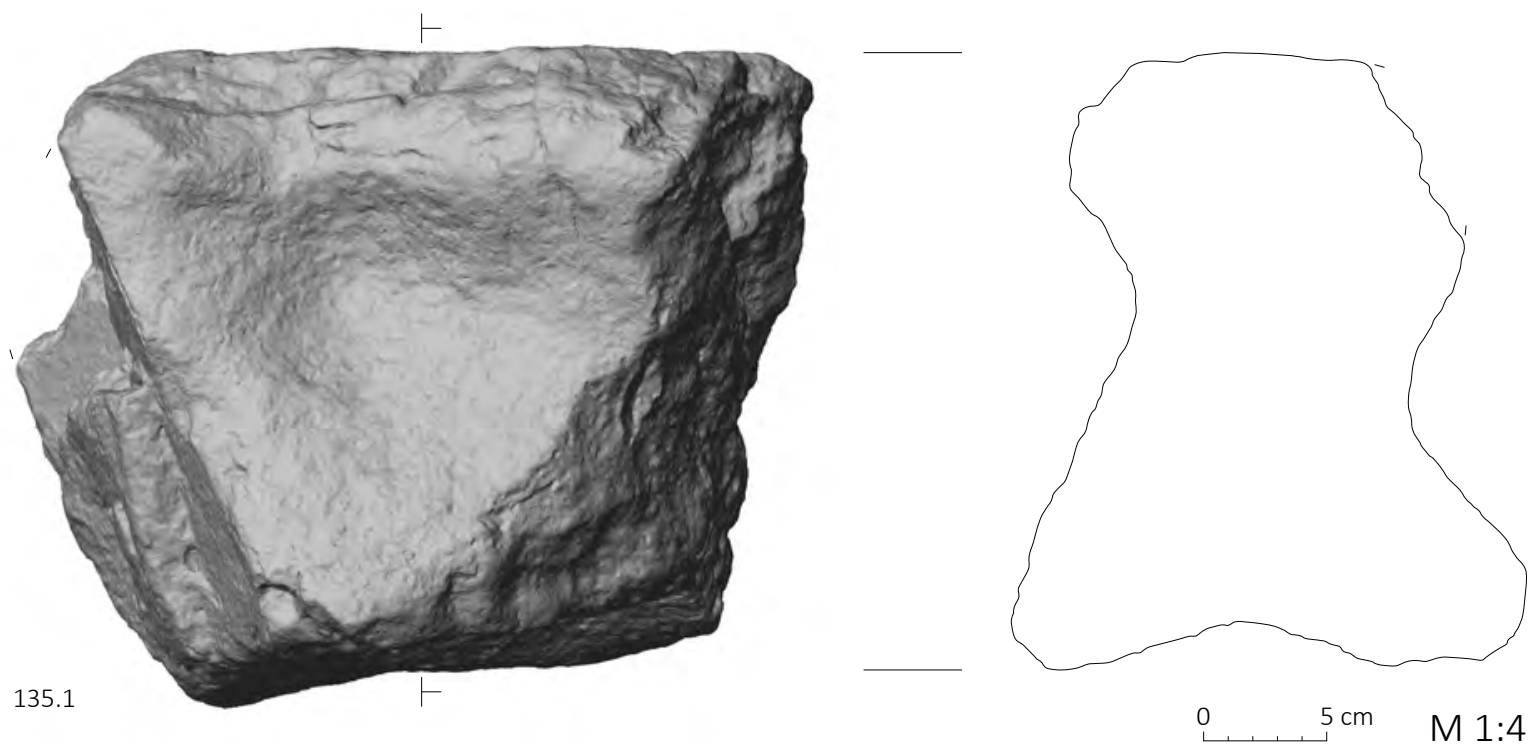

Fig. 19. Stone tools. - Avagna-Ochsenalp: pestle (18203.146.1). - Cotschens: pestles (18203.138.1/139.1), grinder (18203.137.1), anvil stones (18203.135.1/142.1) (3D models: A. Zwicky, ADG; illustration: L. Reitmaier-Naef, UZH).

$700 \mathrm{~g}$, which indicates the use of much larger tools. Traces of use can be seen in the form of worn edges and flaking around the longest perimeter.

The anvil stones are heterogenous in appearance, despite the small sample size. Two anvil stones are complete (18203.136.1/Fig. 19, 18203.142.1), three are damaged (Fig. 19, 18203.135.1) or fragmented (18203.143.1/144.1).
They vary in size, from 20 to $30 \mathrm{~cm}$ in length and a weight of 3 to $7.5 \mathrm{~kg}$, to the largest blocks which are over $40 \mathrm{~cm}$ in length and weigh almost $30 \mathrm{~kg}$. The raw material is usually local stone that was roughly hewn into shape. Flaking is rare and only found on the ridges and flat surfaces. Dimples in the surfaces of the stones, sometimes on several surfaces of the same stone, attest to the use of these stone tools. Their 
size ranges from small, shallow dimples of a few centimetres in diameter to hollows over $20 \mathrm{~cm}$ wide and over $4 \mathrm{~cm}$ deep. The diameter and depth of the dimples remain in proportion to one another: the wider hollows are also deeper than smaller ones.

The final stone object found in this area is a fragment of a grinder (Fig. 19, 18203.137.1) made from biotite-diorite. Originally roughly loaf-shaped, the artefact has broken off diagonally. It has a length of $22 \mathrm{~cm}$ and a weight of approximately $5.5 \mathrm{~kg}$. The underside is noticeably flat and slightly convex, which supports an interpretation as a grinder. The slight roughness of the surface may indicate that the tool was not in use long before it broke.

\subsection{Dating}

Absolute dates could only be gained with material samples collected from around the central outcrop zone of Cotschens. Since a reliable dendrochronological date was not possible in any case, additional radiometric age determination was carried out (Fig. 20).

The cemented material from the heap southeast of mine 1 yielded a dendrochronological date (b-quality/ uncertain dating) with the end year 1131 BC. Because the mean curve extrapolated from the two charcoal fragments $(18203.1109 .3,18203.1109 .6)$ is relatively short (56 tree rings), this date was further ensured through wiggle-matching. For this, ${ }^{14} \mathrm{C}$ samples of the youngest and oldest tree rings were analysed. However, the $2 \sigma$ range $(94.4 \%$ confidence) of the youngest tree rings lies between 1362 and $1278 \mathrm{BC}$ - over 150 years earlier than the putative dendrochronological date. ${ }^{33}$ The cause of this deviation from the otherwise internally consistent wiggle-matching is as yet unclear and cannot be clarified with the progression of the calibration curve. It cannot be estimated how many tree rings are missing between the end year $1131 \mathrm{BC}$, which remains the most likely date despite the lack of consistency with the ${ }^{14} \mathrm{C}$ results, and the waney edge.

The wood artefacts found in mine 1 all date to younger periods. The spatula (67457.38.1) dates to the Hallstatt period, although here, too, the distance missing between the sampled tree rings and the waney edge cannot be determined. The samples from the east profile documented in mine 1 also date to the Early Iron Age. The charred rib fragment from an animal the size of an ovicaprid (67457.36.1), found in the uppermost burned layer, and a charcoal fragment (67457.120.1) from the lowest burned layer were also dated. Both dates fall into the Hallstatt plateau and thus date

33 For raw data of ${ }^{14} \mathrm{C}$ and dendrochronology, see Fig. 20 and Appendix 1 (supplementary data). the lower half of the stratigraphy to the early $8^{\text {th }}$ to the mid$6^{\text {th }}$ century BC.

The shovel-like tool (Fig. 18, 67457.9.1), the trough fragment (Fig. 18, 67457.28.1) and the partially preserved trough (Fig. 18, 67457.22.1) all date to the later La Tène period. For the latter, the most likely synchronisation of the tree ring series lies at the end year 67 BC. For the artefacts dating to the La Tène period, only a few tree rings are missing before the waney edge, meaning any significant old wood effect can be ruled out.

Younger ${ }^{14} \mathrm{C}$ dates confirm that there was occasional activity in the mine after this period (Fig. 21). A contorted, charred wood artefact dates to the Roman period (67457.18.1; near waney edge). The tally stick (Fig. 18, 67457.30.1; near waney edge), a lighting taper (67457.35.2; near waney edge) and the fragment of a shaft (67457.25.1; near waney edge) date to the modern period. Other wood artefacts such as a matchstick (67457.35.3), a snow pole (67457.13.1) and a roof batten (67457.12.1) are also clearly modern.

\subsection{Mineralization}

The mineralizations in Cotschens, like the majority of copper mineralizations in the area, are embedded in a serpentinite sequence of the Platta nappe. ${ }^{34}$ Several mineralizations can be differentiated in the central outcrop zone of Cotschens, two of which are relevant for the study of prehistoric copper mining (Fig. 22):

1. A first type of mineralization (type 1) occurs in the eastern area of the central outcrop zone (mine 1) and comprises pyrrhotite, chalcopyrite and minor bornite. It is generally associated with ilavite and the host rock is serpentinite, particularly antigorite.

The analysed samples show high concentrations of $\mathrm{FeO}$ (>30 wt-\%) and $\mathrm{SiO}_{2}$ (approx. $30 \mathrm{wt}-\%$ ) and $\mathrm{MgO}$ (up to $15 \mathrm{wt}-\%)$ and only minor copper (<3 wt-\%), which confirms the findings of the optical microscopy. $\mathrm{MgO}$ is a characteristic secondary component of serpentinites and indicates - along with the low $\mathrm{Cu}$ content - a high amount of host rock in the sample material. Geochemistry also shows higher levels of $\mathrm{Ni}, \mathrm{Cr}$ (>240 ppm) and Co (30-400 ppm) and very low proportions of $\mathrm{Ag}, \mathrm{Sb}$ and $\mathrm{As}$ which is typical for mineralizations in serpentinites. Copper produced from these ores is characterized by low impurities apart from a certain Ni content and as such is easily discernible from copper produced from fahlores (Tabs. 3a-3b).

The samples were taken from heap material because the in-situ mineralization was not accessible. However, in the eastern area of the central outcrop zone, the heap material

34 Dietrich 1972. 


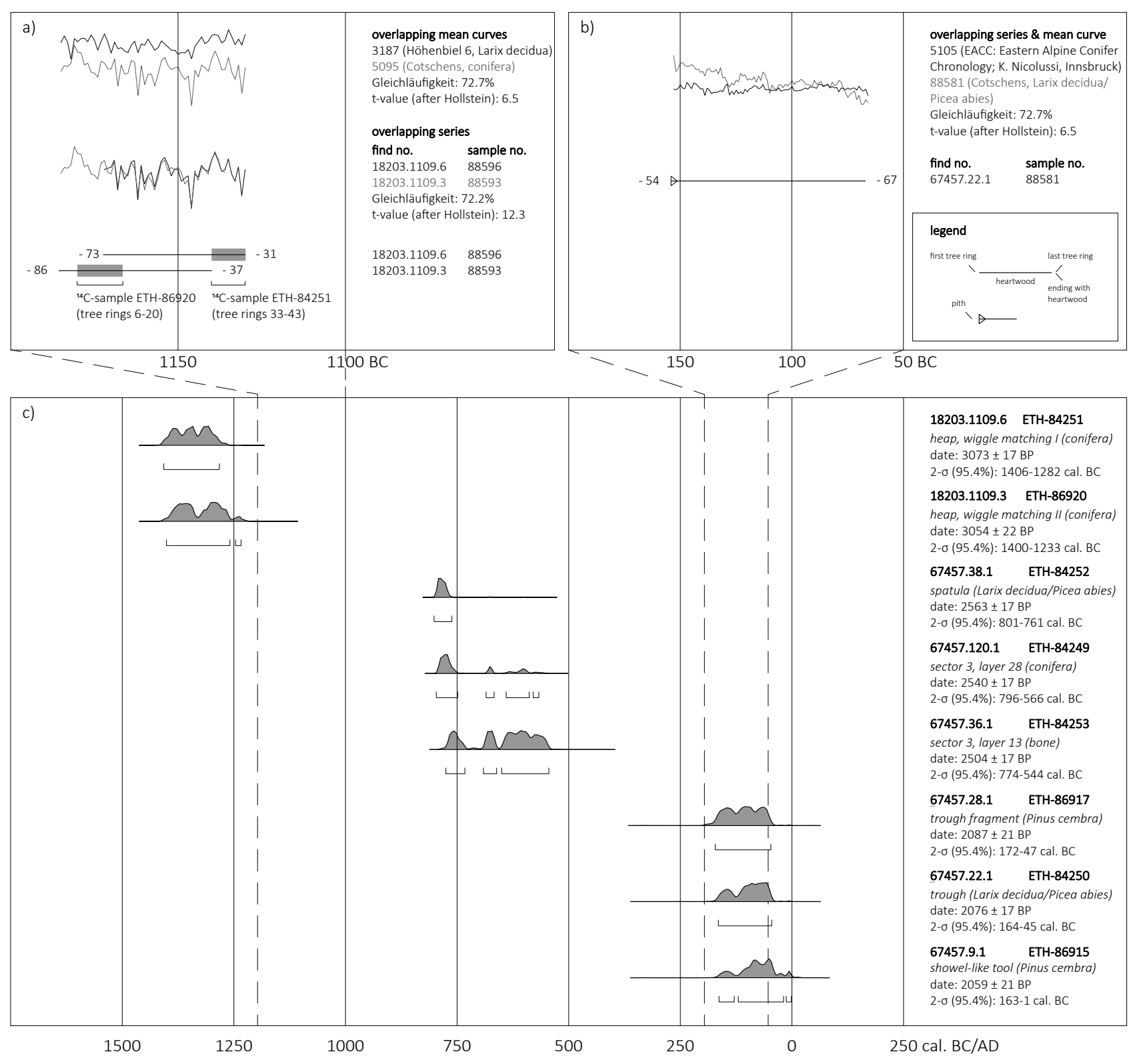

Fig. 20. Cotschens, central outcrop zone and mine 1, absolute dates. - a. Dendrochronological dates from charcoal from the heap. - b. Dendrochronological date of the trough (67457.22.1). - c. ${ }^{14} \mathrm{C}$ dates from prehistoric wood objects, charcoal fragments and bones from mine 1 and the surrounding heap (Illustration: L. Reitmaier-Naef, UZH).

contains this ore paragenesis quite regularly and it can be assumed that the ore extracted from mine 1 corresponds to this first type of mineralization.

2. A further, copper-rich mineralization is situated at the northwestern edge of the central outcrop zone. An undated opencast of several metres in length exposes the mineralization, which was sampled directly from the ore vein. This mineralization is mainly comprised of the copper-rich minerals bornite and chalcocite, with very small amounts of remaining chalcopyrite. In contrast to the first mineralization type and the majority of local copper ore mineralization, this mineralization is embedded in a pale metabasalt host rock. The mineralization runs northeast-southwest through the almost vertically inclining diabase dyke that traverses the outcrop zone, following the junction of the diabase and the surrounding serpentinite.

In comparison to mineralization type 1 , this sample is comprised of $\mathrm{SiO}_{2}, \mathrm{CaO}$ and $\mathrm{Al}_{2} \mathrm{O}_{3}$, with significantly lower 


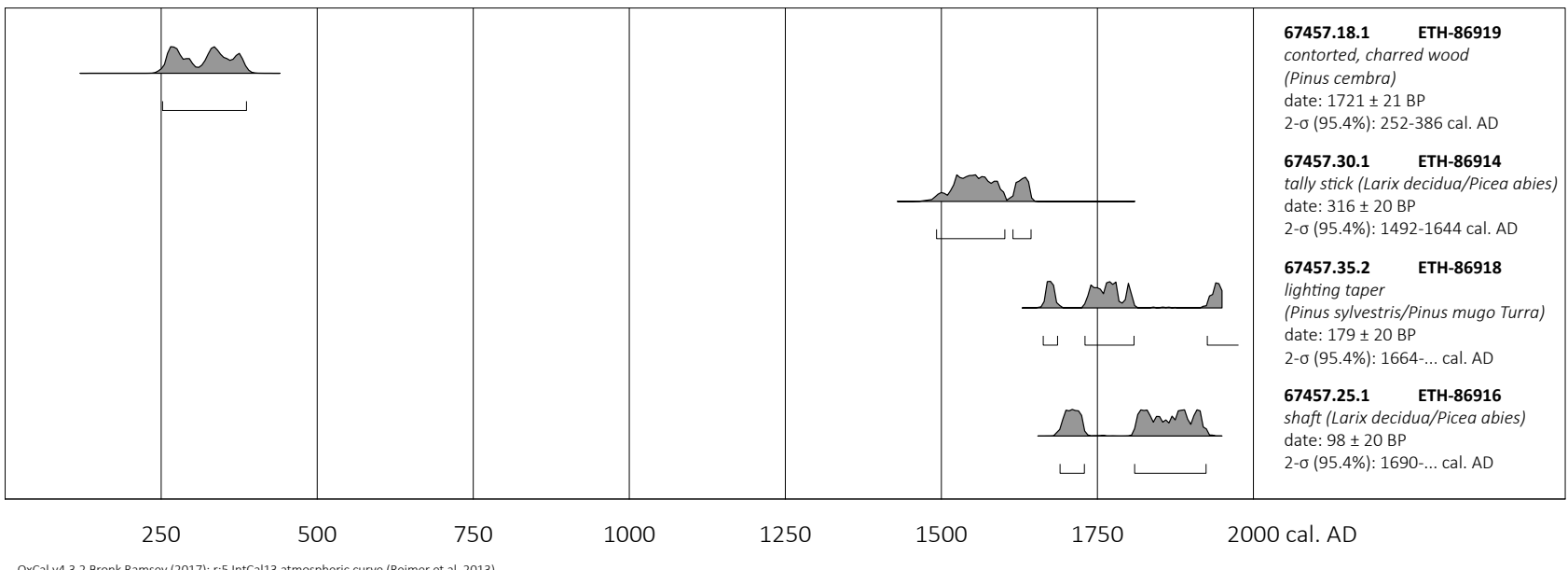

Fig. 21. Cotschens, mine $1,{ }^{14} \mathrm{C}$ dates for wood objects dating from the Roman to the modern period (Illustration: L. Reitmaier-Naef, UZH).

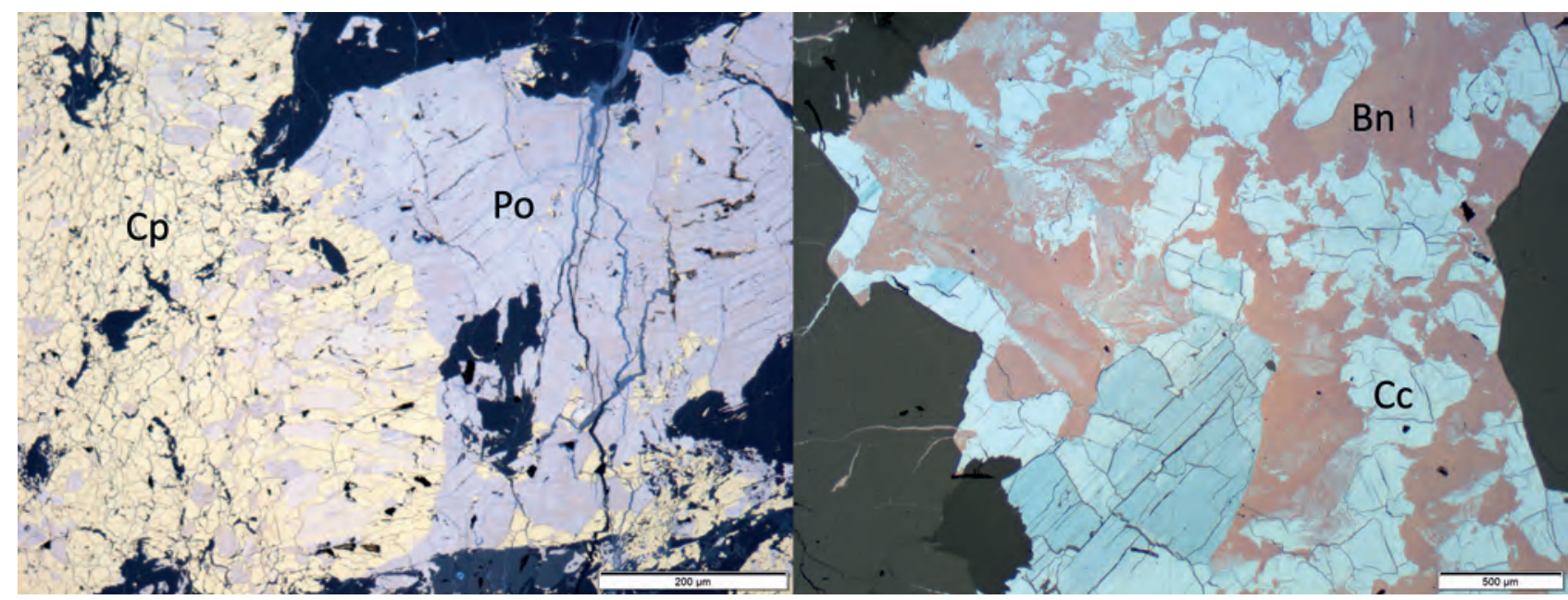

Fig. 22. Cotschens, cross sections (reflected light). - Sample 4948-C1 (left), type 1: chalcopyrite (Cp) and pyrrhotite (Po). - Sample 4046-C2 (right), type 2: copper-rich mineralization with eutectic intergrowth of bornite (Bn) and chalcocite (Cc) (Photos: L. Reitmaier-Naef, UZH).

$\mathrm{MgO}$ and $\mathrm{FeO}$ levels. Both types also show substantial variation in their trace element content: the analysed sample of type 2 shows only very low amounts of trace elements, of which only $\mathrm{Ni}, \mathrm{Co}, \mathrm{Ag}$ and Se are slightly higher (4080 ppm).

It is unclear if this raw material was extracted and processed in prehistory. Considering the high copper content of the mineralization, however, it seems entirely conceivable and would have been achievable with the technology available at the time.

\subsection{Interpretation Cotschens}

To date, the mining area of Cotschens has yielded the most finds from a prehistoric mining context in the Oberhalbstein region. The extensive outcrop zones are strewn with traces of mining activity whose differing characteristics, as well as recognizable superimpositions, show spatial as well as chronological succession. In concrete terms, this can be demonstrated for mine 1 , which was the subject of mining archaeological investigations in 2017.

The mine feature is mainly characterized by rounded cavities which may have been created through fire-setting. This interpretation is supported by the charcoal contained in the infill and by burned layers turned red by intense heat. Radiocarbon dates place these layers in the Hallstatt period, making this the earliest and, so far, the most extensive known operational phase of the mine. A spatula, which may have been used for haulage, also dates to this period. 


\begin{tabular}{|c|c|c|c|c|c|c|c|c|c|c|c|c|c|c|}
\hline Sample & $\mathrm{SiO}_{2}$ & $\mathrm{TiO}_{2}$ & $\mathrm{Al}_{2} \mathrm{O}_{3}$ & $\mathrm{FeO}$ & $\mathrm{MgO}$ & $\mathrm{MnO}$ & $\mathrm{CaO}$ & $\mathrm{Na}_{2} \mathrm{O}$ & $\mathrm{K}_{2} \mathrm{O}$ & $\mathrm{P}_{2} \mathrm{O}_{5}$ & $\mathrm{~S}$ & $\mathrm{Cu}$ & $\mathrm{ZnO}$ & $\mathrm{Sum}$ \\
\hline $4433-\mathrm{C} 1$ & 30,5 & 0,03 & 0,65 & 35,2 & 11,6 & 0,24 & 4,54 & $<0,025$ & 0,003 & 0,003 & 2,57 & 2,67 & 0,10 & 88 \\
\hline $4429-\mathrm{C} 1$ & 31,6 & 0,05 & 0,83 & 32,7 & 14,0 & 0,23 & 3,96 & $<0,025$ & 0,004 & 0,005 & 1,78 & 2,04 & 0,02 & 87 \\
\hline $4048-\mathrm{C} 1$ & 28,0 & 0,01 & 1,28 & 41,3 & 15,0 & 0,20 & 0,83 & 0,21 & 0,017 & 0,005 & 7,46 & 0,59 & 0,04 & 95 \\
\hline $4046-\mathrm{C} 2$ & 22,5 & 0,16 & 11,78 & 5,3 & 1,1 & 0,16 & 19,00 & 0,20 & 0,019 & 0,005 & 10,07 & 29,42 & 0,08 & 100 \\
$\mathbf{n}$
\end{tabular}

\begin{tabular}{|c|c|c|c|c|c|c|c|c|c|c|c|c|}
\hline Sample & $\mathrm{Cr}$ & $\mathrm{Co}$ & $\mathrm{Ni}$ & $\mathrm{Pb}$ & $\mathrm{U}$ & $\mathrm{As}$ & $\mathrm{Sb}$ & $\mathrm{Ag}$ & $\mathrm{Se}$ & $\mathrm{Te}$ & $\mathrm{Bi}$ & $\mathrm{Sn}$ \\
\hline $4433-\mathrm{C} 1$ & 1400 & 70 & 490 & 5 & 0,86 & 4 & 1,6 & 7,8 & $<10$ & 1,2 & 0,1 & 3 \\
\hline $4429-\mathrm{C} 1$ & 1600 & 30 & 240 & 5 & 0,86 & 4 & 3,5 & 3,8 & $<10$ & 1,3 & 0,1 & 3 \\
\hline $4048-\mathrm{C} 1$ & 2200 & 400 & 1200 & $<3,5$ & 0,02 & 6 & 0,6 & 0,5 & $<10$ & $<2$ & 0,1 & $<2$ \\
\hline $4046-\mathrm{C} 2$ & 10 & 40 & 50 & 15 & 0,03 & 8 & 0,9 & 60,0 & 80 & 4,1 & $<0,1$ & 9 \\
b
\end{tabular}

Tab. 3. Cotschens, general chemical analysis (ICP-MS) of ore samples. - a. Major and secondary components in wt.- \%, total in \%. The total iron content was calculated as FeO. - b. Trace elements in ppm. - All samples were measured in the DBM laboratory.

Mining tools dating to the $2^{\text {nd }}$ and $1^{\text {st }}$ centuries BC confirm another operational phase in the La Tène period. Both the fragmented troughs and the shovel-like tool date to this phase. The infill in the upper part of the mine may have been removed in this period, in order to clear out the lower-lying parts of the mine. The position of one of the troughs found in the drifts suggests that the two north-facing drifts may have been created during these activities. Unlike in the earlier phase, where fire-setting was likely used, the structure of the drifts suggests the use of metal tools in their driving. The activity carried out in this second operational phase is on a much smaller scale, suggesting prospection work which was not followed by more extensive mining.

Later dates attest to occasional activity in the mine into the modern period, but further mining operations cannot be derived from this. The absence of any iron objects in the mine and on the surrounding heaps, which are reliable indicators of medieval and modern mining activities, also suggests that no more recent mining activities were undertaken. ${ }^{35}$

However, an earlier, Late Bronze Age operational phase is confirmed by dating from the heap close to the mine. While this cannot be definitively connected to mine 1 , the inclusion of the charcoal in the heap material clearly indicates mining activity.

The stone tools found on the surface, at the edge of the heaps, can generally be placed in a prehistoric ore extraction context. While anvil stones were used into the modern period, ${ }^{36}$ hand-held stone crushing tools were not, nor was the

35 E.g. СЕсH 2007.

36 See CЕсH 2007. fragment of a grinder. ${ }^{37}$ The spectrum of tools for crushing and grinding confirms a beneficiation process with at least two stages performed directly in the mining area ${ }^{38}$ - to date, this is a unique find in the Oberhalbstein region.

\section{Summary and Outlook}

Mining archaeological investigations completed in 2017 provided reliable evidence of prehistoric copper ore mining in the two mining areas of Avagna-Ochsenalp and Cotschens. The features, which primarily date to the Late Bronze Age and the Early Iron Age, fit chronologically into the larger context of the previously known local Alpine archaeological landscape. The well-preserved Alpine mining tools found in the flooded mine 1 in Cotschens provided new evidence of small-scale mining activity during the Late Iron Age. These finds are so far unique to the Alps. ${ }^{39}$

In addition to the historical use of these two mining areas, the identification of processing equipment at both sites is of particular importance, as evidence of this stage of the copper production has so far been completely lacking in archaeological finds from this area. A detailed investigation of suspected processing sites therefore seems especially promising for future research. In connection with further investigations on the well-preserved, finds-rich strata in the heap and mine areas, a characterization of individual mining and processing steps could be achieved, as well as a better general understanding of the mining and exploitation methods used. It may also be possible to construct a detailed

\footnotetext{
37 Domergue et al. 1997.

38 STÖLLNER et al. 2012.

39 See Morin, Tizzoni 2009. - Stöllner 2009.
} 
chronology of individual operating phases using stratified charcoal sample series. An extensive analysis of wood and charcoal material could also supply valuable information regarding how the prehistoric miners used their resources. Mining in extreme altitudes of up to 2500 masl would have entailed significant logistical and technological difficulties, especially considering the smelting sites nearby, which consumed significant amounts of wood. First bone finds from the sediment of the mine additionally indicate the possibility of further finds from otherwise largely unknown aspects of life - for example the material culture or the diet of the miners - as has been achieved in similar fire-set mines in the Lower Inn Valley, which have proved exceptionally rich in finds. ${ }^{40}$

Climatic constraints probably meant that the mining activity in Cotschens and Avagna-Ochsenalp was seasonal and stood in conjunction with other Late Bronze Age and Early Iron Age usage of the Alpine landscape. An intensification in the use of Alpine pastures can be observed in the same period, indicating a possible increase in the territorial occupation of the landscape and its resources. ${ }^{41}$

Questions remain concerning the geographical and cultural provenance of the miners and their knowledge of mining and metallurgy in the different periods of activity, as well as the market for copper from the Oberhalbstein region. The extrapolation of a copper signature for the Oberhalbstein region provides a promising basis for further provenance-analytical investigations, considering that the copper produced here can be relatively well differentiated from that of other Alpine regions due to its trace element pattern and lead isotope ratio. ${ }^{42}$

\section{Acknowledgements}

The investigations in Cotschens and Avagna-Ochsenalp were undertaken as part of the international research project 'Prehistoric copper production in the Eastern and Central Alps - technical, social and economic dynamics in space and time', with the support of the Austrian Science Fund (FWF), the Swiss National Science Foundation (SNF) and the German Research Foundation (DFG), and the participation of the Department of Prehistory of the University of Zurich (UZH), the Archaeological Service of the Canton of Grisons, the Deutsches Bergbau-Museum Bochum and the HiMAT Research Center of the University of Innsbruck. The demanding fieldwork and evaluations could not have been accomplished without the active support of numerous other people and institutions. We would like to thank: Amanda Zwicky and Christoph Walser from the Archaeological Service of Canton Grisons (ADG) for the creation of digital terrain and object models; the Swiss Air Force for the free transport

40 Goldenberg et al. 2011. - Staudt et al. 2019 - Saliari et al. in press.

41 Walsh, Mocci 2011. - Reitmaier 2017.

42 Reitmaier-Naef 2018. flights; Luisa Karrer, Matti Keller, Sepp Beeler, Jann Rehm, Elsbeth Rehm and Andreas Schatzmann from the Freunde des Bergbaus Graubünden (FBG) for draining mine 1; Zurich University students Stephanie Hug, Joëlle Jäger, Pierina Roffler and Mario Stockmaier for their vigorous support in the field; Hans Peter Schenk for discovering the pestle in Avagna-Ochsenalp; Kurt Nicolussi (Laboratory for Dendrochronology, University of Innsbruck) and Niels Bleicher (Laboratory for Dendrochronology, City of Zurich) for their support in the evaluation of dendrochronological results; Werner H. Schoch (Laboratory for Ancient Wood Research, Langnau am Albis) for microscope photos and some of the wood anatomy determinations; the team of the Deutsches Bergbau-Museum Bochum (DBM) for the creation of the plans of mine 1 (Gero Steffens, Fabian Schapals) and the ore analysis (Andreas Hauptmann, Michael Bode, Michael Prange, Jan Sessing); Kylie Rüegger (University of Zurich) for the translation; the team at the Archaeological Service of the Canton of Grisons for documenting, illustrating and preserving the finds - especially Lea Gredig for the drawing of the wood objects; and the municipality of Surses and various landowners, tenants and residents for their organizational support.

\section{Appendix 1}

Supplementary raw data of ${ }^{14} \mathrm{C}$ and dendrochronology related to this article can be found at: doi: 10.1553/archaeologia104s123-A.

\section{References}

BRUN 1987

E. BRUn, Geschichte des Bergbaus im Oberhalbstein. Davos-Platz 1987.

\section{BRÜGGER 1866}

C. BRÜGgER, Der Bergbau in den X Gerichten und der Herrschaft Rhäzüns unter der Verwaltung des Davoser Berg-Richters, Christian Gadmer, 1588-1618: Ein culturgeschichtlicher Beitrag, Jahresbericht der Naturforschenden Gesellschaft Graubündens N. F. 11/1864-1865, 1866, 47-80.

BUJARD 1910

A. BuJARD, Zündwaren. Leipzig 1910.

Cech 2007

B. СЕCH, Spätmittelalterliche bis frühneuzeitliche Edelmetallgewinnung in den Hohen Tauern: Montanarchäologische Forschungen im Bockhartrevier, Gasteiner Tal (Bundesland Salzburg). Monographien des Römisch-Germanischen Zentralmuseums 70, Mainz 2007.

Della Casa, Naef, Turck 2016

P. Della Casa, L. Naef, R. Turck, Prehistoric copper pyrotechnology in the Swiss Alps: approaches to site detection and chaîne opératoire, Quaternary International 402, 2016, 26-34.

DiETRICH 1972

V. Dietrich, Die sulfidischen Vererzungen in den Oberhalbsteiner Serpentiniten: Ein Beitrag zur Kenntnis der alpinen Metamorphosen und des Gebirgsbaues im südlichen Graubünden. Beiträge zur Geologie der Schweiz, Geotechnische Serie 49, Bern 1972.

Domergue et al. 1997

C. Domergue, D. Bézat, B. Cauuet, C. Jarrier, C. Landes, J.-C. Morasz, P. Oliva, R. Pulou, F. Tollon, Les moulins rotatifs dans les mines et les centres métallurgiques antiques. In: D. Garcia, D. Meers (Eds.), Techniques et économie antiques et médiévales: Le temps de l'innovation. Paris 1997, 47-61. 
FASNACHT 2004

W. Fasnacht, Prähistorischer Kupferbergbau in den Schweizer Alpen I. In: G. Weisgerber, G. Goldenberg (Eds.), Alpenkupfer-Rame delle Alpi. Der Anschnitt, Beiheft 17, Bochum 2004, 107-111.

Goldenberg et al. 2011

G. Goldenberg, E. Breitenlechner, S. Deschler-Erb, K. Hanke, G. Hiebel, H. Hüster-Plogmann, S. Hye, M. Klaunzer, K. Kovács, M. Krismer, J. Lutz, A. MaAss, M. Moser, K. Nicolussi, K. Oeggl, E. Pernicka, T. Pichler, N. Pöllath, J. Schibler, M. Staudt, B. Stopp, A. Thurner, U. Töchterle, G. Tomedi, P. Tropper, F. Vavtar, T. Weinhold, Prähistorischer Kupfererzbergbau im Maukental bei Radfeld/Brixlegg. In: G. Goldenberg, U. Töchterle, K. Oeggl, A. Krenn-Leeb (Eds.), Forschungsprogramm HiMAT - Neues zur Bergbaugeschichte der Ostalpen. Archäologie Österreichs Spezial 4, Vienna 2011, 61-110.

Hitz 2012

F. Hiтz, Die Herren von Marmels: Soziale Stellung und politische Rolle. In: U. Jecklin-Tischhauser, L. Frascoli, M. Janosa (Eds.), Die Burg Marmels: Eine bündnerische Balmburg im Spiegel von Archäologie und Geschichte. Schweizer Beiträge zur Kulturgeschichte und Archäologie des Mittelalters 40, Basel 2012, 201-226.

KOCH WALDNER 2017

T. Koch WALDNER, Räumliche und zeitliche Struktur des prähistorischen Bergbaus in der Region Kitzbühel: Charakterisierung einer alpinen bronzezeitlichen Bergbaulandschaft anhand von archäologischen Befunden, Geländeanalysen und überregionalen Vergleichen. Unpublished PhD Dissertation, University of Innsbruck 2017.

Morin, Tizzoni 2009

D. Morin, M. Tizzoni, Aux origines des techniques minières: L'exploitation d'un gisement filonien au Premier Âge du fer: Les mines de Silter di Campolungo et de Baita Cludona di Fondo (Val Camonica, Alpes lombardes, Italie), Bulletin de la Société préhistorique française 106/1, 2009, 109-141.

OBERHÄNSLI et al. 2019

M. Oberhänsli, M. Seifert, N. Bleicher, W. H. Schoch, L. Reitmaier-Naef, R. Turck, T. Reitmaier, P. Della Casa, Dendrochronological dating of charcoal from high-altitude prehistoric copper mining sites in the Oberhalbstein Valley (Grisons, Switzerland). In: R. Turck, T. Stöllner, G. Goldenberg (Eds.), Alpine Copper II: New Results and Perspectives on Prehistoric Copper Production. Der Anschnitt, Beiheft 42, Bochum 2019, 245-260.

Perini 1987

R. PERINI, Scavi Archeologici nella Zona palafitticola di Fiavé-Carera, Parte II: Campagne 1969-1976, Resti della Cultura Materiale: Metallo - Osso - Litica - Legno. Trento 1987.

Peters, Dietrich 2008

T. Peters, V. Dietrich, Bivio [Geologische Karte und Erläuterungen]. Geologischer Atlas der Schweiz 1:25.000, LK 1256. Bern 2008.

RAGETH 1986

J. Rageth, Die wichtigsten Resultate der Ausgrabungen in der bronzezeitlichen Siedlung auf dem Padnal bei Savognin (Oberhalbstein GR), Jahrbuch der Schweizerischen Gesellschaft für Ur- und Frühgeschichte 69, 1986, 63-103.

\section{ReitMaier 2017}

T. Reitmaier, Prähistorische Alpwirtschaft: Eine archäologische Spurensuche in der Silvretta (CH/A), 2007-2016, Jahrbuch Archäologie Schweiz 100, 2017, 7-53.

Reitmaier-NAEF 2018

L. Reitmaier-Naef, Vom Erz zum Metall: Die chaine opératoire der prähistorischen Kupfergewinnung im Oberhalbstein GR. Unpublished PhD Dissertation, University of Zurich 2018.

Reitmaier-Naef, Turck, Della Casa 2015

L. Reitmaier-Naef, R. Turck, P. Della Casa, Prähistorische Kupfergewinnung im Oberhalbstein, Minaria Helvetica 36, 2015, $35-54$.

Rentzel et al. 2017

P. Rentzel, C. Nicosia, A. Gebhardt, D. Brönnimann, C. PümpIN, K. Ismail-Meyer, Trampling, poaching and the effect of traffic. In: C. Nicosia, G. Stoops (Eds.), Archaeological Soil and Sediment Micromorphology. Hoboken 2017, 281-297.

SALIARI et al. in press

K. Saliari, E. Pucher, M. Staudt, G. Goldenberg, Continuities and changes of animal exploitation across the Bronze Age - Iron Age boundary at mining sites in the Eastern Alps, Archaeofauna - International Journal of Archaeozoology, in press.

SANDS 1997

R. SAnds, Prehistoric Woodworking: The Analysis and Interpretation of Bronze and Iron Age Toolmarks. Wood in Archaeology 1, London 1997.

SCHAER 2003

A. SchaER, Untersuchungen zum prähistorischen Bergbau im Oberhalbstein (Kanton Graubünden), Jahrbuch der Schweizerischen Gesellschaft für Ur- und Frühgeschichte 86, 2003, 7-54.

STAUDT et al. 2019

M.Staudt, G. Goldenberg, M.Scherer-Windisch, K. Nicolussi, T. Pichler, Late Bronze Age/Early Iron Age fahlore mining in the Lower Inn Valley (North Tyrol, Austria). In: R. Turck, T. Stöllner, G. Goldenberg (Eds.), Alpine Copper II: New Results and Perspectives on Prehistoric Copper Production. Der Anschnitt, Beiheft 42, Bochum 2019, 115-142.

\section{STEBLLER 1907}

F. StEBler, Die Hauszeichen und Tesseln der Schweiz, Schweizerisches Archiv für Volkskunde 11, 1907, 165-209.

STEINER 2010

H. STEINER, Dank und Bitte an die Götter: Vorgeschichtliche Holzfunde auf der Schöllberg-Göge (Gem. Ahrntal/Südtirol). In: F. Mandl, H. Stadler (Eds.), Archäologie in den Alpen: Alltag und Kult. Forschungsberichte der ANISA 3, Haus i. E. 2010, 253-358.

STEINER et al. 2009

H. Steiner, A. Putzer, H. Oberrauch, A. Thurner, K. NicoLussi, Vorgeschichtliche Moorfunde auf der Schöllberg-Göge in Weissenbach (Gde. Ahrntal/Südtirol), Archäologisches Korrespondenzblatt 39/4, 2009, 489-508.

STÖLLNER 2009

T. STÖLLNER, Die zeitliche Einordnung der prähistorischen Montanreviere in den Ost- und Südalpen: Anmerkungen zu einem Forschungsstand. In: K. Oeggl, M. Prast (Eds.), Die Geschichte des Bergbaus in Tirol und seinen angrenzenden Gebieten. Innsbruck 2009, 37-60. 
STÖLLNER et al. 2012

T. Stöllner, E. Breitenlechner, D. Fritzsch, A. Gontscharov, K. Hanke, K. Kovács, M. Moser, K. Nicolussi, K. Oeggl, T. Pichler, R. Pils, M. Prange, H. Thiemeyer, P. Thomas, Ein Nassaufbereitungskasten vom Troiboden: Interdisziplinäre Erforschung des bronzezeitlichen Montanwesens am Mitterberg (Land Salzburg, Österreich), Jahrbuch des Römisch-Germanischen Zentralmuseums Mainz 57/1/2010, 2012, 1-32.

Theobald 1862

G. Theobald, Cima da Flix und Piz Err mit ihrer Umgebung, Jahresbericht der Naturforschenden Gesellschaft Graubündens N. F. 7/1860-1861, 1862, 5-54.

Thомаs 2018

P. Thomas, Studien zu den bronzezeitlichen Bergbauhölzern im Mitterberger Gebiet. Der Anschnitt, Beiheft 38, Bochum 2018.

Timberlake 2014

S. Timberlake, The study of cobble stone, bone, antler and wooden mining tools in prehistoric metal mining: new evidence from the British Isles and beyond. In: Research and Preservation of Ancient Mining Areas. $9^{\text {th }}$ International Symposium on Archaeological Mining History. Institute Europa Subterranea Yearbook 2014, Trento 2014, 26-55.

TURCK 2019

R. TURCK, Organising smelting places: a keynote on Iron Age copper smelting in the Oberhalbstein (Canton of Grisons, Switzerland). In: R. Turck, T. Stöllner, G. Goldenberg (Eds.), Alpine Copper II: New Results and Perspectives on Prehistoric Copper Production. Der Anschnitt, Beiheft 42, Bochum 2019, 209-228.

Turck, Della Casa, Naef 2014

R. Turck, P. Della Casa, L. Naef, Prehistoric copper pyrotechnology in the south-eastern Swiss Alps: an overview on previous and current research. In: J. Bullinger, P. CRotTi, C. Huguenin (Eds.), De l'âge du Fer à l'usage du verre. Cahiers d'Archéologie Romande 151, Lausanne 2014.

Turck et al. 2018

R. Turck, A. Winkler, M. Stockmaier, P. Della Casa, T. Reitmaier, M. Seifert, M. Oberhänsli, D. Kopp, Surses GR, Marmorera, Gruba II [Fundbericht], Jahrbuch Archäologie Schweiz 101, 2018, 264.

Walsh, Mocci 2011

K. WALSH, F. Mocci, Mobility in the mountains: late third and second millennia Alpine societies' engagements with the high-altitude zones in the southern French Alps, European Journal of Archaeology 14/1-2, 2011, 88-115.

WeIss 1941

R. Weiss, Das Alpwesen Graubündens: Wirtschaft, Sachkultur, Recht, Älplerarbeit und Älplerleben. Erlenbach-Zürich 1941.

Wyss 1993

R. Wyss, Prähistorische Kupfererzgewinnung in den Schweizer Alpen, Zeitschrift für Schweizerische Archäologie und Kunstgeschichte 50/3, 1993, 195-212.

Wyss 2004

R. Wyss, Prähistorischer Kupferbergbau in den Schweizer Alpen II. In: G. Weisgerber, G. Goldenberg (Eds.), Alpenkupfer - Rame delle Alpi. Der Anschnitt, Beiheft 17, Bochum 2004, 113-116.
Leandra Reitmaier-Naef

Institute of Archaeology

Department of Prebistoric Archaeology

University of Zurich

Karl Schmid-Strasse 4 8006 Zurich

Switzerland

leandra.reitmaier@gmx.ch

orcid.org/0000-0003-1946-2574

Peter Thomas

Research Department for Mining Archaeology

Deutsches Bergbau-Museum Bochum

Am Bergbaumuseum 31

44791 Bochum

Germany

peter.thomas@bergbaumuseum.de

orcid.org/0000-0003-1731-0294

Julia Bucher

Institute of Archaeology

Department of Prebistoric Archaeology

University of Zurich

Karl Schmid-Strasse 4

8006 Zurich

Switzerland

julia.bucher@googlemail.com

orcid.org/0000-0002-0209-5125

Monika Oberbänsli
Archaeological Service of the Canton of Grisons
Loëstrasse 26
7000 Chur
Switzerland
monika.oberhaensli@adg.gr.ch
(D) orcid.org/0000-0003-1958-0765

Caroline O. Grutsch

Institute of Archaeologies

Research Center HiMAT

University of Innsbruck

Langer Weg 11

6020 Innsbruck

Austria

caroline.grutsch@student.uibk.ac.at

orcid.org/0000-0001-6819-8111

Klaus-Peter Martinek

Marlene-Dietrich-Straße 49 80636 München

Germany

kpmartinek@t-online.de orcid.org/0000-0001-9321-7898 
Mathias Seifert
Archaeological Service of the Canton of Grisons
Loëstrasse 26
7000 Chur
Switzerland
mathias.seifert@adg.gr.ch
Philippe Rentzel Integrative Prebistory and Archeological Science IPAS

University of Basel

Spalenring 145 4055 Basel

Switzerland philippe.rentzel@unibas.ch orcid.org/0000-0002-7518-7987

Rouven Turck Institute of Archaeology Department of Prebistoric Archaeology University of Zurich Karl Schmid-Strasse 4 8006 Zurich Switzerland rouven.turck@uzh.ch D orcid.org/0000-0001-9534-6570

Thomas Reitmaier Archaeological Service of the Canton of Grisons Loëstrasse 26 7000 Chur

Switzerland thomas.reitmaier@adg.gr.ch orcid.org/0000-0003-3810-5839

Philippe Della Casa Institute of Archaeology Department of Prebistoric Archaeology University of Zurich Karl Schmid-Strasse 4 8006 Zurich Switzerland philippedellacasa@uzh.ch orcid.org/0000-0002-9787-0082 